\title{
Article \\ Potential Valorization of Waste Tires as Activated Carbon-Based Adsorbent for Organic Contaminants Removal
}

\author{
Kawthar Frikha ${ }^{1}$, Lionel Limousy ${ }^{1}$, Joan Pons Claret ${ }^{2}$, Cyril Vaulot ${ }^{1} \mathbb{1}$, Karin Florencio Pérez ${ }^{2}$, \\ Beatriz Corzo Garcia ${ }^{2}$ and Simona Bennici ${ }^{1, * \text { (D) }}$ \\ 1 Institut de Sciences des Matériaux de Mulhouse, Université de Haute-Alsace, 15 Rue Jean Starcky, \\ F-68057 Mulhouse, France; kawthar.frikha@uha.fr (K.F.); lionel.limousy@uha.fr (L.L.); \\ cyril.vaulot@uha.fr (C.V.) \\ 2 Sorigué, Ronda Guinardó, 99, 08041 Barcelona, Spain; J.Pons@sorigue.com (J.P.C.); \\ k.florencio@sorigue.com (K.F.P.); b.corzo@sorigue.com (B.C.G.) \\ * Correspondence: simona.bennici@uha.fr ; Tel.: +33-38-933-6729
}

Citation: Frikha, K.; Limousy, L.; Pons Claret, J.; Vaulot, C.; Pérez, K.F.; Garcia, B.C.; Bennici, S. Potential Valorization of Waste Tires as Activated Carbon-Based Adsorbent for Organic Contaminants Removal. Materials 2022, 15, 1099. https:// doi.org/10.3390/ma15031099

Academic Editor: Alain Celzard

Received: 28 December 2021

Accepted: 27 January 2022

Published: 30 January 2022

Publisher's Note: MDPI stays neutral with regard to jurisdictional claims in published maps and institutional affiliations.

Copyright: (C) 2022 by the authors. Licensee MDPI, Basel, Switzerland. This article is an open access article distributed under the terms and conditions of the Creative Commons Attribution (CC BY) license (https:// creativecommons.org/licenses/by/ $4.0 /)$.

\begin{abstract}
The present study investigates the potential of waste tires to produce a valuable adsorbent material for application in wastewater treatment. In the first stage, the pyrolysis of ground rubber tire was explored using non-isothermal and isothermal thermogravimetric analysis experiments. The effect of operating parameters, such as heating rate and pyrolysis temperature, on the pyrolysis product yields was considered. The slow pyrolysis of ground rubber tire was taken up in a largescale fixed-bed reactor for enhanced char recovery. Four pyrolysis temperatures were selected by thermogravimetric data. The product yields were strongly influenced by the pyrolysis temperature; at higher temperatures, the formation of more gases and liquid was favored, while at lower pyrolysis temperatures, more char (solid fraction) was formed. The produced chars were characterized in terms of mineral composition, textural properties, proximate analysis, and structural properties to identify the relationships between the pyrolysis temperature and the char properties. In a second step, a series of activated chars were prepared, starting from the pyrolytic chars via chemical and/or physical activation methods. Then, the activated chars were characterized and tested as adsorbents for atrazine and ibuprofen. Adsorption experiments in aqueous media were carried out in a small-scale batch reactor system. Chemical activation seems appropriate to significantly reduce the inorganic compounds initially present in ground rubber tire and contribute to an important increase in the surface area and porosity of the chars. Adsorption experiments indicated that chemically activated chars exhibit high aqueous adsorption capacity for atrazine.
\end{abstract}

Keywords: waste tires; ground rubber tire; pyrolysis; char; activation; activated char; adsorption; wastewater treatment

\section{Introduction}

Over the past two decades, the increase in vehicle industry has generated a huge amount of waste tires [1]. About 4 billion tons of waste tires are generated every year, all over the world [2]. The European Union (EU), North America, and Southeast Asia take up $90 \%$ of the world's waste tires generation [3]. The increase in the amounts of waste tires is well exemplified by the EU, in which more than 2.7 million tons of waste tires are generated every year [4]. To reduce the waste tires flow generation, the EU implemented council directive on end-of-life vehicles (2000), which provided measures and guidance on waste tires management [5]. The main routes for waste tires management are landfilling, energy recovery, material recovery, retreading, and reuse/export [6]. Meanwhile, the council directive on the landfill of waste (1999) banned the landfilling of waste tires by 2006 [7]. Tires are mainly composed of natural and/or synthetic rubber; a vulcanization agent such as sulfur; carbon black as a reinforcing filler; steel cords; textile fibers; and other additives, such as zinc oxide, as a vulcanization activator. The diverse composition of tires makes 
their energy and/or material recovery a profitable business. Moreover, the high calorific value (28-37 $\left.\mathrm{MJ} \mathrm{kg}^{-1}\right)$ of tires, as well as the low mineral matter, make tires a potential non-fossil energy source [1]. However, some energy recovery routes, such as incineration or combustion, may lead to the emission of hazardous compounds and metals [4]. To minimize the negative impacts of waste management on the environment, such as those caused by the energy recovery routes, thermal recycling of waste tire materials through pyrolysis can be considered the most convenient practice [8]. Waste tires pyrolysis is an innovative alternative for waste tires management, producing fuel and other solid products in a more environmentally friendly manner. Indeed, lower amounts of hazardous gas, such as nitrogen oxides $\left(\mathrm{NO}_{\mathrm{x}}\right)$ and sulfur oxides $\left(\mathrm{SO}_{\mathrm{x}}\right)$, and better quality of the solid residue can be produced due to the inert atmosphere in the pyrolysis process [9]. During the pyrolysis process, the organic volatile matter of tires, mainly the rubber polymers, are decomposed to lower molecular weight products, oils, and gases, while the inorganic compounds and the nonvolatile carbon black, contained in the waste tire, remain as solid char residue [10]. Many research groups have demonstrated that pyrolytic oils can be used as fuels [11-16] or chemical feedstock [17-19], the gas can be used as a process fuel [20-23], and the char has the potential to be used as carbon black or activated carbon (AC) [24-26]. The yields and characteristics of pyrolysis products depend on the waste tires feedstock (composition and particle size) and the operating parameters, such as temperature, heating rate, vapors/solid residence time, and atmosphere. The pyrolysis of waste tires in an inert atmosphere at 300-900 ${ }^{\circ} \mathrm{C}$ has been studied by many researchers, and the effects of operating conditions on the product yields (gases, oils, and char) have been reported [12,27]. In a study [12], pyrolysis of waste tires was carried out in a fixed-bed reactor at $300-700{ }^{\circ} \mathrm{C}$ at a heating rate of $15{ }^{\circ} \mathrm{C} \mathrm{min}{ }^{-1}$. Char yield decreased when temperature increased from 300 to $500{ }^{\circ} \mathrm{C}$, whereas liquid and gas yields increased. In another study [27], pyrolysis of waste tires was carried out in a fixed-bed reactor at $300-720{ }^{\circ} \mathrm{C}$ at a heating rate of $5{ }^{\circ} \mathrm{C} \min ^{-1}$. As the pyrolysis temperature increased from 300 to $720{ }^{\circ} \mathrm{C}$, the char yields decreased from 94 to $39 \mathrm{wt} \%$, the oil yield increased from 3.6 to $55 \mathrm{wt} \%$, and the gas yield increased from 2.4 to $6.4 \mathrm{wt}$ \%. Processing this carbonaceous residue into a high-value product, such as carbon-based adsorbent or catalyst support [28,29], is an interesting option. Chars derived from the pyrolysis of waste tires could be used as adsorbents for gas storage or pollution control applications. The surface area of an adsorbent is generally a key parameter when considering its adsorption properties. Chars derived from the pyrolysis of waste tires were found to have surface areas of 30-90 $\mathrm{m}^{2} \mathrm{~g}^{-1}$ [24-27], which are too low for use as an adsorbent as compared to a commercial carbon-based adsorbent. The activation process is often employed to improve the textural and chemical properties of carbon materials, using both heat and an activating agent. During activation, the activating agent diffuses into the char pores, causing a chemical reaction with the carbon atoms and loss of carbon. The reaction rate is influenced by multiple factors, such as the activating agent, the char composition, the ash content, the textural properties of the char, the reaction temperature, and the reaction time [30-34]. Basically, there are two different activation processes for the preparation of activated char: the so-called chemical and physical activation. Chemical activation consists of impregnation of the char with a chemical activating reagent, such as zinc chloride, phosphoric acid, sodium hydroxide, potassium carbonate, or potassium hydroxide, followed by carbonization of the impregnated char at temperatures between 600 and $850{ }^{\circ} \mathrm{C}$, in an inert atmosphere [35-38]. Physical activation involves a thermal treatment of the char under an oxidizing atmosphere up to $1100^{\circ} \mathrm{C}$ using gaseous oxidizing agents, such as carbon dioxide, steam, air, or a mixture of these [12-14].

The potential of waste tire-derived AC as adsorbents has been evaluated in both aqueous $[39,40]$ and gas media [41,42], achieving adsorption capacities equivalent to those obtained with commercial AC or to those obtained at laboratory scale from other carbon sources, such as biomass waste [43,44], agri-food waste [45], textile waste [46], and municipal waste [47]. Concerning the environmental impact on the preparation of AC, to our knowledge, there are no published studies examining the environmental impact 
of the preparation of $\mathrm{AC}$ from ground rubber feedstock from a Life Cycle Assessment (LCA) perspective. However, some studies $[48,49]$ on the environmental impact of the preparation of AC, using other types of waste as feedstock, are available in the literature. In one study [48], the authors have found that the environmental impacts of the preparation of AC, at laboratory scale, are mainly dominated by the activation process, specifically the impregnation step, due to the use of a chemical activation agent. The global warming potential impact was found to be $11 \mathrm{~kg} \mathrm{CO}$-equivalent $/ \mathrm{kg}$ AC. The steps involving feedstock production, feedstock logistics, and AC logistics presented low environmental impacts $(0-6.4 \%)$. In another study [49], the authors demonstrated that the production of AC from brewery waste, at laboratory scale, complies with the ISO 14040 standard on LCA.

Regarding the industrial aspect of this study, the LCA on AC production, at laboratory and industrial scales, from waste tires is worth conducting to quantify the emission of hazardous materials, resources consumed, and the impact of the use of AC on the environment. From a qualitative point of view, the negative environmental impact of the preparation of AC from ground rubber feedstock can be managed, especially if certain modifications are incorporated into the production process of $\mathrm{AC}$, such as recovery of $\mathrm{KOH}$ after AC washing, recovery of the energy from pyrolysis and activation hot gases, pyrolysis/activation gas recovery for reuse as an energy source, and regeneration of the used AC after water treatment application. Moreover, AC production using waste tires not only contributes to the development of materials for water environment treatment, but also contributes to the waste tires management. In addition, oil-based fuels production using waste tires provides increased benefits with respect to the development of alternative energy resources with low environmental impacts compared with nonrenewable fossil resources.

The aim of the present work is to study the potential valorization of an industrial waste, waste tires, as an adsorbent material for organic contaminants removal. For this purpose, the production of activated chars from waste tires was investigated via pyrolysis and activation process. The effects of the different treatments on the chemical and textural properties of the resulting carbon materials (char and activated chars) were investigated. The adsorption characteristics of the obtained activated chars in aqueous media were also investigated, where atrazine and ibuprofen were used as representative adsorbates.

\section{Materials and Methods}

\subsection{Waste Tires Feedstock}

Ground rubber with an average particle of 1.5-4 $\mathrm{mm}$ was used as the char precursor feedstock. The recycled ground rubber was supplied by Sorigué, Spain and produced from a combination of cars' (60 wt.\%) and trucks' $(40 \mathrm{wt} . \%)$ waste tires.

The used ground rubber is a standardized material classified following the ASTM D 5603 "Standard Classification for Rubber Compounding Materials—Recycled Vulcanized Rubber". This classification covers the compounding material commercially known as recycled vulcanized particulate rubber.

The picture of the ground rubber sample is shown in Figure 1. The characteristics of the ground rubber feedstock, including moisture content, volatile matter content, fixed carbon content, ash content, Element's concentrations, and total polycyclic aromatic hydrocarbon concentration are presented in Table 1.

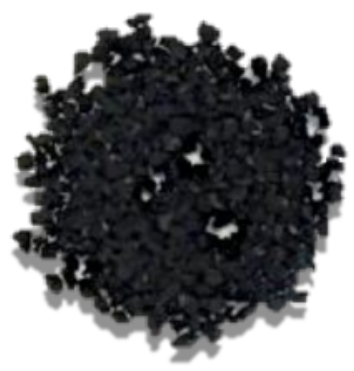

Figure 1. Picture of the ground rubber feedstock. 
Table 1. Characteristics of the ground rubber feedstock.

\begin{tabular}{|c|c|c|}
\hline Proximate Analysis (wt.\%, as Received) & Analysis Method & Result \\
\hline Moisture & \multirow{4}{*}{$\begin{array}{c}\text { Thermogravimetric Analysis } \\
\text { (TGA) }\end{array}$} & 0.4 \\
\hline Volatile matter & & 67.5 \\
\hline Fixed carbon & & 27.3 \\
\hline Ash & & 4.7 \\
\hline \multicolumn{3}{|l|}{ Elemental Analysis (mg kg ${ }^{-1}$, dry basis) } \\
\hline As & \multirow{12}{*}{$\begin{array}{l}\text { Inductively Coupled Plasma } \\
\text { Mass Spectrometry (ICP-MS) }\end{array}$} & 0.05 \\
\hline $\mathrm{Cd}$ & & 0.05 \\
\hline Cr total & & $<0.25$ \\
\hline $\mathrm{Pb}$ & & 4.2 \\
\hline $\mathrm{Mn}$ & & 1 \\
\hline Se & & $<0.5$ \\
\hline $\mathrm{Ba}$ & & 7.5 \\
\hline $\mathrm{B}$ & & 1.5 \\
\hline $\mathrm{Sb}$ & & $<0.5$ \\
\hline Co & & $<0.05$ \\
\hline $\mathrm{Sr}$ & & 0.85 \\
\hline Sn & & $<0.5$ \\
\hline $\mathrm{Al}$ & \multirow{4}{*}{$\begin{array}{c}\text { Inductively Coupled Plasma } \\
\text { Atomic Emisssion } \\
\text { Spectrometry (ICP-AES) }\end{array}$} & 16.5 \\
\hline $\mathrm{Cu}$ & & 122 \\
\hline $\mathrm{Ni}$ & & $<0.25$ \\
\hline $\mathrm{Zn}$ & & 700 \\
\hline Cr III & NF EN ISO 11885 & $<0.25$ \\
\hline Cr VI & NF T 90-043 & $<0.20$ \\
\hline $\mathrm{Hg}$ & NF EN ISO 17852 & $<0.005$ \\
\hline $\begin{array}{l}\text { Total Polycyclic Aromatic Hydrocarbon } \\
\text { (mg kg }{ }^{-1} \text {, dry basis) }\end{array}$ & US EPA 8270 & $<43.26$ \\
\hline
\end{tabular}

Proximate analysis was conducted according to the ASTM D7582-15 standard using a TOLEDO TGA/DSC 3+ thermogravimetric analyzer. About $15 \mathrm{mg}$ of ground rubber sample were heated at a heating rate of $5^{\circ} \mathrm{C} \mathrm{min}^{-1}$ to $900{ }^{\circ} \mathrm{C}$ under a nitrogen atmosphere with a gas flow rate of $100 \mathrm{~mL} \mathrm{~min}^{-1}$ and held isothermally under a nitrogen atmosphere for $10 \mathrm{~min}$. Then the atmosphere was switched to air $\left(100 \mathrm{~mL} \mathrm{~min}^{-1}\right)$ for $60 \mathrm{~min}$. Element's concentrations were determined by inductively coupled plasma mass spectrometry (ICPMS) and inductively coupled plasma atomic emission spectrometry (ICP-AES), according to the NF EN ISO 11885, NF T 90-043, and NF EN ISO 17852 standards provided by LABOSPORT laboratory.

\subsection{Thermogravimetric Analysis Experiments}

Two sets of thermogravimetric analysis (TGA) experiments were carried out to evaluate the effect of heating rate and temperature on the char yield and thermal degradation behavior of the ground rubber sample. A TOLEDO TGA/DSC $3+$ thermogravimetric analyzer was used for all the experiments. Experimental protocol details and operating conditions are given in Table 2. For the non-isothermal experiments, the ground rubber samples were heated from 35 to $900{ }^{\circ} \mathrm{C}$ at a chosen heating rate $\left(5,10\right.$, and $\left.20{ }^{\circ} \mathrm{C} \mathrm{min}{ }^{-1}\right)$, followed by a $10 \mathrm{~min}$ hold at $900{ }^{\circ} \mathrm{C}$ and then a $60 \mathrm{~min}$ hold at $900{ }^{\circ} \mathrm{C}$ in an oxidizing environment. For the isothermal experiments, first, the samples were heated from $35{ }^{\circ} \mathrm{C}$ to the chosen temperature $\left(450,500,550\right.$, and $\left.600{ }^{\circ} \mathrm{C}\right)$ with a heating rate of $5{ }^{\circ} \mathrm{C} \mathrm{min}$ m $^{-1}$ and then kept under isothermal conditions for $180 \mathrm{~min}$. Second, the samples were heated from the isothermal temperature to $900{ }^{\circ} \mathrm{C}$, followed by a $60 \mathrm{~min}$ hold at $900{ }^{\circ} \mathrm{C}$ and then a $10 \mathrm{~min}$ hold at $900{ }^{\circ} \mathrm{C}$ in an oxidizing environment. For all the experiments, the gas


initial mass sample was about $10-15 \mathrm{mg}$. For each experiment, the proximate analysis data-volatile matter, fixed carbon, and ash content-were determined. 
Table 2. Details of the TGA experimental protocols.

\begin{tabular}{|c|c|c|}
\hline \multicolumn{3}{|c|}{ Experimental Protocol for Non-Isothermal Tests: Study of the Influence of Heating Rate } \\
\hline Step & Description & Stage \\
\hline 1 & hold for $10 \mathrm{~min}$ at $35^{\circ} \mathrm{C}$ under $\mathrm{N}_{2}$ & initial \\
\hline 2 & ramp to $900^{\circ} \mathrm{C}$ with ramp rate of 5,10 and $20^{\circ} \mathrm{C} \min ^{-1}$ under $\mathrm{N}_{2}$ & heating \\
\hline 3 & hold at $900{ }^{\circ} \mathrm{C}$ for $10 \mathrm{~min}$ under $\mathrm{N}_{2}$ & isothermal \\
\hline 4 & hold at $900{ }^{\circ} \mathrm{C}$ for $60 \mathrm{~min}$ under air & isothermal \\
\hline 5 & cool to room temperature under air & cooling \\
\hline \multicolumn{3}{|c|}{ Experimental Protocol for Isothermal Tests: Study of the Influence of Pyrolysis Temperature } \\
\hline Step & Description & Stage \\
\hline 1 & hold for $10 \mathrm{~min}$ at $35^{\circ} \mathrm{C}$ under $\mathrm{N}_{2}$ & initial \\
\hline 2 & ramp to $\mathrm{T}$ pyrolysis with ramp rate of $5^{\circ} \mathrm{C} \min ^{-1}$ under $\mathrm{N}_{2}$ & heating \\
\hline 3 & hold at $\mathrm{T}$ pyrolysis for $3 \mathrm{~h}$ under $\mathrm{N}_{2}$ & isothermal \\
\hline 4 & ramp to $900{ }^{\circ} \mathrm{C}$ with ramp rate of $5^{\circ} \mathrm{C} \mathrm{min}^{-1}$ under $\mathrm{N}_{2}$ & heating \\
\hline 5 & hold at $900{ }^{\circ} \mathrm{C}$ for $60 \mathrm{~min}$ under $\mathrm{N}_{2}$ & isothermal \\
\hline 6 & hold at $900^{\circ} \mathrm{C}$ for $10 \mathrm{~min}$ under air & isothermal \\
\hline 7 & cool to room temperature under air & cooling \\
\hline
\end{tabular}

\subsection{Pilot-Scale Pyrolysis Experiments}

Pilot-scale pyrolysis experiments were carried out in a fixed-bed reactor, externally heated by an electrical furnace. The reactor was fully instrumented in terms of gas flow control, furnace temperature control, and temperature monitoring throughout. A condenser system was used to trap the condensable gases (liquids). Non-condensable gases were sent into a carbon filtration unit before reaching the atmosphere. Three pyrolysis assays were performed under a nitrogen atmosphere with the same solid residence time at the temperatures of 450,500 , and $550{ }^{\circ} \mathrm{C}$. Since the water content of the ground rubber was too low, there was no need to dry the sample before the pyrolysis experiments. Before the pyrolysis experiment, the reactor was purged with a nitrogen gas flow of $10 \mathrm{~L} \mathrm{~min}^{-1}$ for $10 \mathrm{~min}$ to remove air. In a typical pyrolysis experiment, approximately $2.6 \mathrm{~kg}$ of ground rubber sample were introduced into the reactor, heated at a controlled rate of $5^{\circ} \mathrm{C} \mathrm{min}-1$ to the desired pyrolysis temperature, and held at that temperature for $3 \mathrm{~h}$. During the pyrolysis experiment, the reactor was purged continuously with nitrogen at a fixed flow rate of $10 \mathrm{~L} \mathrm{~min}^{-1}$ to remove away the evolved gases from the reaction zone, thus reducing the eventual secondary reactions, such as thermal cracking, repolymerization, and recondensation. After completion of the pyrolysis, the reactor was left to cool down, and the solid residue was recovered from the reactor and weighed to determine the mass of the char produced. The char samples obtained at the three pyrolysis temperatures were labeled as BC450, BC500, and BC550. The condensed liquid collected at the end of the experiment was weighed to determine the mass of the oil (tar) product. The char, oil, and gas product yields were calculated relative to the initial sample mass using Equations (1)-(3):

$$
\begin{gathered}
\text { Char yield }(\text { wt. } \%)=\frac{\text { Mass of char }}{\text { Mass of sample }} \times 100 \\
\text { Tar yield }(\text { wt. } \%)=\frac{\text { Mass of tar }}{\text { Mass of sample }} \times 100 \\
\text { Gas yield }(\text { wt. } \%)=100-\text { Char yield }- \text { Tar yield }
\end{gathered}
$$

\subsection{Activation Experiments}

The char obtained at a pyrolysis temperature of $450{ }^{\circ} \mathrm{C}$ (BC450) was selected as precursor for activated char production. Prior to activation, the char sample was sieved to 1.5-4 mm particle size. In this work, we adopted three activation methods to generate the activated char, including chemical activation (CA), physical activation (PA) and combined chemical-physical activation (CPA) (chemical activation followed by physical activation). 
The chemical activation experiment involved the impregnation of the char with potassium hydroxide $(\mathrm{KOH}, \geq 85 \%$, Fluka, Steinheim, Germany) as the activating agent, followed by heating the chemically impregnated char at $700{ }^{\circ} \mathrm{C}$ for $3 \mathrm{~h}$ in a nitrogen-purged quartz-tube reactor, externally heated by an electric vertical furnace. The scheme of the reactor used for activation experiments is shown in Figure 2. After heat treatment, the activated char was cooled under nitrogen purge and then washed and filtered several times with distilled water until the $\mathrm{pH}$ of the filtrate was around 7 . Finally, the washed sample was dried at $105{ }^{\circ} \mathrm{C}$ for $24 \mathrm{~h}$ in air. Physical activation was carried out in a quartz-tube reactor using carbon dioxide as the activating agent. A char sample of about $3 \mathrm{~g}$ was introduced into the reactor (Figure 2) and heated from an ambient temperature to $850{ }^{\circ} \mathrm{C}$ under nitrogen flow $\left(100 \mathrm{~mL} \mathrm{~min}^{-1}\right)$ at a heating rate of $5^{\circ} \mathrm{C} \mathrm{min}^{-1}$. When the target activation temperature was reached, the inert atmosphere was substituted by carbon dioxide with a flow rate of $100 \mathrm{~mL} \mathrm{~min}^{-1}$. The reactor temperature was held at $850{ }^{\circ} \mathrm{C}$ for $2 \mathrm{~h}$ and then cooled to room temperature under a nitrogen atmosphere. For the combined chemical-physical activation experiment, the activated char produced by chemical activation experiment was subjected to subsequent physical activation, in which time activation lasted only for $20 \mathrm{~min}$. The activated char was weighed to calculate the activated char production yield. The activated char yield was calculated using equation 4 . The activated char samples obtained through chemical, physical, and combined chemical-physical activations were labeled as CA-BC450, PA-BC450, and CPA-BC450, respectively.

$$
\text { Activated char yield }(\text { wt. } \%)=\frac{\text { Mass of activated char }}{\text { Mass of char }} \times 100
$$

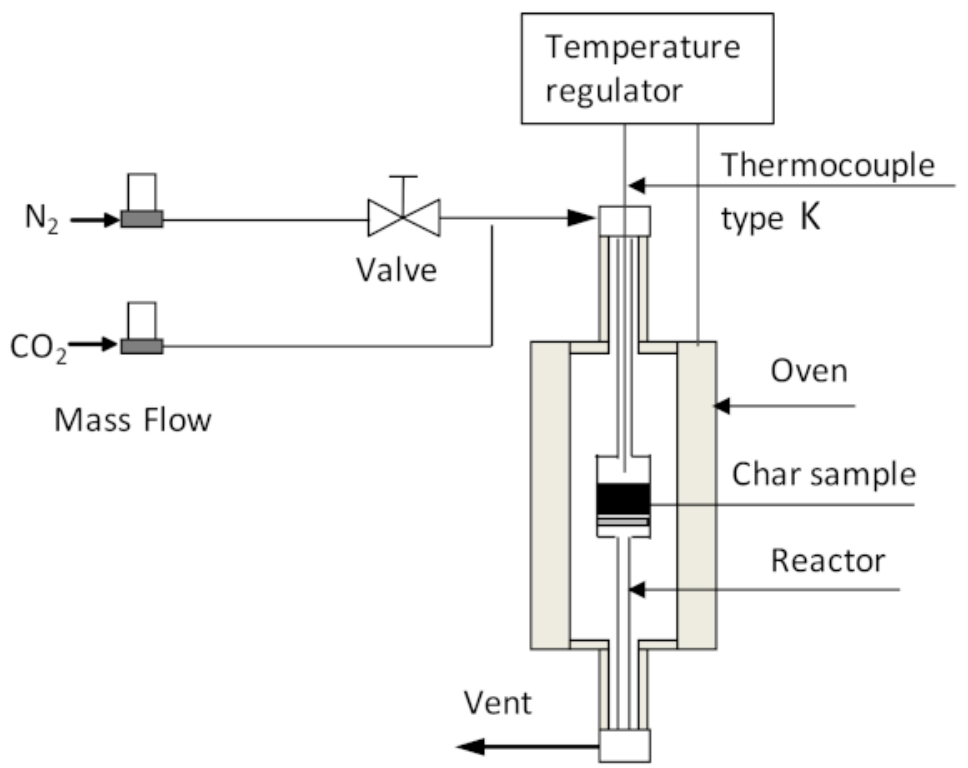

Figure 2. Scheme of installation used for activation experiments.

\subsection{Chemical and Physical Characterization}

Physical and chemical characterization were performed on the char and activated char samples to gain insight into the properties of tire-derived char sorbents. Such properties include proximate analysis, ultimate analysis, surface area and micropore volume analysis, point of zero charge (PZC) measurements, scanning electron microscopy (SEM), energy dispersive X-ray spectrometry (EDX), X-ray diffraction analysis (XRD) and Raman spectroscopy.

Proximate analysis was conducted according to the ASTM D7582-15 standard using a TOLEDO TGA/DSC 3+ thermogravimetric analyzer. An approximately $20 \mathrm{mg}$ sample were heated at $5^{\circ} \mathrm{C} \mathrm{min}^{-1}$ to $900{ }^{\circ} \mathrm{C}$ under a nitrogen atmosphere with a constant gas flow rate of $100 \mathrm{~mL} \mathrm{~min}^{-1}$ and held isothermally under the nitrogen atmosphere for $10 \mathrm{~min}$. Afterwards, the gas flow was switched from nitrogen to air, and the temperature was held 
at $900{ }^{\circ} \mathrm{C}$ for $60 \mathrm{~min}$. Weight loss up to $105^{\circ} \mathrm{C}$ represents moisture content. The weight loss between 105 and $900{ }^{\circ} \mathrm{C}$ represents the volatile matter content. The residue remaining after combustion in the air at $900{ }^{\circ} \mathrm{C}$ represents ash. Fixed carbon content was determined by difference.

Surface area and micropore volume analysis was conducted on a Micromeritics ASAP2420 volumetric gas adsorption apparatus using $\mathrm{N}_{2}$ or $\mathrm{CO}_{2}$ as a gas adsorbate at $-196{ }^{\circ} \mathrm{C}$ and $0{ }^{\circ} \mathrm{C}$, respectively. Before gas adsorption measurements, the samples were outgassed under vacuum at $200{ }^{\circ} \mathrm{C}$ for $10 \mathrm{~h}$. Surface area and micropore volume were determined by applying Brunauer-Emmet-Teller (BET) and t-plot methods, respectively. Total pore volume and average pore diameter were determined using the standard BarrettJoyner-Halenda $(\mathrm{BJH})$ method applied to the desorption branch of the nitrogen isotherm.

Ultimate analysis was performed with a Wavelength Dispersive X-ray Fluorescence (WDXRF) using a PANalytical Zetium $(4 \mathrm{~kW})$ spectrometer. Before analysis, pellets of the samples (13 mm diameter and $1 \mathrm{~mm}$ thick) were obtained by pressing the powders (100 $\mathrm{mg}$ ) under 9-ton pressure during $10 \mathrm{~min}$.

Characterization of the carbon matrix's microstructure was conducted using scanning electron microscopy, Raman spectroscopy, and X-ray diffraction analysis. SEM micrographs were acquired on a JSM 7900 JOEL microscope at $5 \mathrm{kV}$ accelerating voltage. XRD analyses were carried out using a PANalytical MPD X'Pert Pro diffractometer operating with $\mathrm{Cu} \mathrm{K}$ $\alpha$ radiation, $\lambda=0.15406 \mathrm{~nm}$ at $40 \mathrm{~mA}$ and $45 \mathrm{kV}$. Data were recorded at room temperature,

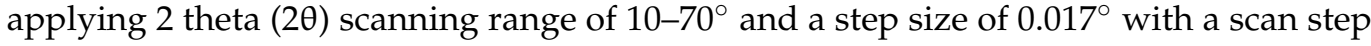
time of 220 s. Raman spectra were recorded with a BX40 LabRam spectrometer equipped with a CCD camera detector. The spectra were acquired with a $50 \times$ lens, an excitation laser operating at a wavelength of $532 \mathrm{~nm}$, and an acquisition time of $180 \mathrm{~s}$.

The point of zero charge (PZC) of the activated chars, known as $\mathrm{pH}_{\mathrm{PZC}}$, corresponds to the $\mathrm{pH}$ value at which the surface has a zero net charge and was determined by the $\mathrm{pH}$ drift method. At $\mathrm{pH}<\mathrm{pH}_{\mathrm{PZC}}$, the char surface has a net positive charge, while at $\mathrm{pH}>\mathrm{pH} \mathrm{PZC}_{\text {, }}$ the surface has a net negative charge. This method consisted of preparing six solutions with initial $\mathrm{pH}$ values between 3 and 13 by diluting aqueous solutions of $0.1 \mathrm{M} \mathrm{NaOH}$ or $0.1 \mathrm{M} \mathrm{HCl}$. Solutions of $50 \mathrm{~mL}$ of each were prepared and piped into glass screw-capped bottles, and $0.1 \mathrm{~g}$ of the activated char was added to each solution. Then, the suspensions were agitated for $48 \mathrm{~h}$ and filtered. The final $\mathrm{pH}$ of each filtrate was measured using a digital $\mathrm{pH}$ meter and plotted against the initial $\mathrm{pH}$. The $\mathrm{pH}_{\mathrm{PZC}}$ point was determined at the point in which $\mathrm{pH}_{\text {final }}$ is equal to $\mathrm{pH}_{\text {initial }}$.

Before characterization, char and activated char samples were dried at $105^{\circ} \mathrm{C}$ for $24 \mathrm{~h}$ and saved in a desiccator to prevent moisture absorption.

\subsection{Aqueous Phase Adsorption Tests}

BC450, CA-BC450, PA-BC450, and CPA-BC450 samples were selected as adsorbents to perform adsorption tests. Atrazine $\left(\mathrm{C}_{8} \mathrm{H}_{14} \mathrm{ClN}_{5}, \geq 98 \%\right.$, Sigma-Aldrich, Steinheim, Germany) and ibuprofen $\left(\mathrm{C}_{13} \mathrm{H}_{18} \mathrm{O}_{2}, \geq 98 \%\right.$, Sigma-Aldrich) were chosen as adsorbates. These organic micro-pollutant adsorbates were used as received without any further purification, and their molecular sizes and structures, which were estimated using ACD/ChemSketch software, are shown in Table 3.

Prior to adsorption tests, the activated carbons were dried overnight in a ventilated oven at $110{ }^{\circ} \mathrm{C}$. Equilibrium adsorption experiments were performed in ambient conditions in separate batch systems, each containing different concentrations of atrazine or ibuprofen. First, stock solutions of $25 \mathrm{mg} \mathrm{L}^{-1}$ atrazine or $20 \mathrm{mg} \mathrm{L}^{-1}$ ibuprofen were prepared by dissolving an appropriate amount of atrazine or ibuprofen in deionized water. Then, four solutions of various initial concentrations were prepared from these stock solutions by sequential dilution using deionized water. The concentration range of each adsorbate was from 5 to $20 \mathrm{mg} \mathrm{L}^{-1}\left(5,10,15\right.$, and $\left.20 \mathrm{mg} \mathrm{L}^{-1}\right)$. 
Table 3. Molecules used as micro-pollutant adsorbates for the liquid phase adsorption experiments.

\begin{tabular}{|c|c|c|c|c|}
\hline Adsorbates & Type & $\begin{array}{l}\text { Molecule } \\
\text { Structure }\end{array}$ & Molecule Size * & $\begin{array}{c}\text { Solubility in } \\
\text { Water }\left(\mathrm{mg} \mathrm{L}^{-1}\right)\end{array}$ \\
\hline $\begin{array}{c}\text { Atrazine } \\
\mathrm{C}_{8} \mathrm{H}_{14} \mathrm{ClN}_{5}\end{array}$ & Herbicide & & $\begin{array}{l}\text { Width } \approx 1 \mathrm{~nm} \\
\text { Depth } \approx 0.8 \mathrm{~nm}\end{array}$ & $21\left(\right.$ at $\left.25^{\circ} \mathrm{C}\right)$ \\
\hline $\begin{array}{l}\text { Ibuprofen } \\
\mathrm{C}_{13} \mathrm{H}_{18} \mathrm{O}_{2}\end{array}$ & $\begin{array}{c}\text { Anti-inflammatory } \\
\text { drug }\end{array}$ & & $\begin{array}{l}\text { Width } \approx 1.3 \mathrm{~nm} \\
\text { Depth } \approx 0.5 \mathrm{~nm}\end{array}$ & 33 (at $25^{\circ} \mathrm{C}$ ) \\
\hline
\end{tabular}

* Determined by ACD/ChemSketch software.

Equilibrium adsorption experiments for each adsorbate were performed by transferring an adequate pre-weighed amount of the dry adsorbent into a set of $50 \mathrm{~mL}$ screw-capped polypropylene centrifuge tubes used as batch reactor systems, each containing $40 \mathrm{~mL}$ of adsorbate solution of different concentrations. The sealed tubes were agitated mechanically at a uniform shaking speed for $48 \mathrm{~h}$ in a horizontal mechanical shaker. This shaking period was sufficient for establishing adsorption equilibrium. The adsorption tests were determined without adding any electrolyte solution into the system to avoid any interference of additional substances in the system. After shaking, the suspensions were filtered through $0.45 \mu \mathrm{m}$ syringe filters, and the residual atrazine or ibuprofen concentration in the filtrate was determined using a Perkin Elmer Lambda 35 UV-Visible spectrophotometer. The absorption spectra were recorded from 200 to $900 \mathrm{~nm}$ with $1 \mathrm{~nm}$ bandwidth, and the absorbance for each solution was measured at $222 \mathrm{~nm}$ (wavelength of maximum absorption). Calibration curves of atrazine and ibuprofen, at different concentrations, were generated by fitting the absorbance as a function of the concentration at the maximum wavelengths of $222 \mathrm{~nm}$. The calibration equations of atrazine and ibuprofen were calculated by linear regression of the calibration curves through the representation of the adsorbate concentration versus the absorbance. The resulting calibration lines presented good determination coefficients $\left(\mathrm{R}^{2}\right)$ of at least 0.998 .

The adsorption capacity at equilibrium $\left(\mathrm{q}_{\mathrm{e}}, \mathrm{mg} \mathrm{g}^{-1}\right)$, corresponding to the amount of atrazine or ibuprofen adsorbed per gram of activated char, and the adsorption efficiency $(\%)$, corresponding to the percentage removal of pollutants by the char or activated char, were calculated using Equations (5) and (6).

$$
\begin{gathered}
\text { Adsorption capacity }\left(\mathrm{q}_{\mathrm{e}^{\prime}}, \mathrm{mg} \mathrm{g}^{-1}\right)=\frac{\left(\mathrm{C}_{0}-\mathrm{C}_{\mathrm{e}}\right) \times \mathrm{V}}{\mathrm{m}} \\
\text { Adsorption efficiency }(\%)=\frac{\left(\mathrm{C}_{0}-\mathrm{C}_{\mathrm{e}}\right) \times 100}{\mathrm{C}_{0}}
\end{gathered}
$$

where $\mathrm{C}_{0}\left(\mathrm{mg} \mathrm{L}^{-1}\right)$ is the initial concentration of solute, $\mathrm{C}_{\mathrm{e}}\left(\mathrm{mg} \mathrm{L}^{-1}\right)$ is the concentration of solute at equilibrium, $\mathrm{V}(\mathrm{L})$ is the volume of the aqueous solution, and $\mathrm{m}(\mathrm{g})$ is the mass of the char/activated char.

The adsorption data of atrazine and ibuprofen were fitted to both Langmuir and Freundlich isotherm models [50-54]. The Langmuir isotherm is commonly applied to monolayer adsorption on a homogeneous adsorbent surface (monolayer adsorption model), and it is given by Equation (7). The constants $\mathrm{q}_{\max }$ and $\mathrm{K}_{\mathrm{L}}$ can be determined from its linearized form (plot of $\mathrm{C}_{\mathrm{e}} / \mathrm{q}_{\mathrm{e}}$ vs. $\mathrm{C}_{\mathrm{e}}$ ):

$$
\mathrm{q}_{\mathrm{e}}=\frac{\mathrm{q}_{\max } \mathrm{K}_{\mathrm{L}} \mathrm{C}_{\mathrm{e}}}{\left(1+\mathrm{K}_{\mathrm{L}} \mathrm{C}_{\mathrm{e}}\right)}
$$


where $\mathrm{q}_{\max }\left(\mathrm{mg} \mathrm{g}^{-1}\right)$ is the maximum adsorption capacity, and $\mathrm{K}_{\mathrm{L}}\left(\mathrm{L} \mathrm{mg} \mathrm{g}^{-1}\right)$ is the Langmuir constant.

The Langmuir equation can be linearized to calculate the parameters $\mathrm{q}_{\max }$ and $\mathrm{K}_{\mathrm{L}}$ using Equation (8) [55] (plot of $\mathrm{C}_{\mathrm{e}} / \mathrm{q}_{\mathrm{e}}$ vs. $\mathrm{C}_{\mathrm{e}}$ ):

$$
\frac{\mathrm{C}_{\mathrm{e}}}{\mathrm{q}_{\mathrm{e}}}=\frac{1}{\mathrm{q}_{\max } \mathrm{K}_{\mathrm{L}}}+\frac{\mathrm{C}_{\mathrm{e}}}{\mathrm{q}_{\max }}
$$

The Freundlich isotherm is employed for adsorption surfaces with nonuniform energy distribution (multilayer adsorption model), and it is given by Equation (9):

$$
\mathrm{q}_{\mathrm{e}}=\mathrm{K}_{\mathrm{F}} \mathrm{C}_{\mathrm{e}}^{\frac{1}{n}}
$$

where $\mathrm{K}_{\mathrm{F}}\left(\mathrm{mg} \mathrm{g}^{-1}\right)$ is the Freundlich adsorption capacity, and $1 / \mathrm{n}$ (dimensionless) is the Freundlich constant related to the surface heterogeneity.

The Freundlich equation can be linearized to calculate the parameters $K_{F}$ and $n$ using Equation (10) (plot of $\ln \left(\mathrm{q}_{\mathrm{e}}\right)$ vs. $\ln \left(\mathrm{C}_{\mathrm{e}}\right)$ ). The adsorption can be considered favorable when $0<1 / \mathrm{n}<1[51]$ :

$$
\ln \left(\mathrm{q}_{\mathrm{e}}\right)=\frac{1}{\mathrm{n}} \ln \left(\mathrm{C}_{\mathrm{e}}\right)+\ln \left(\mathrm{K}_{\mathrm{F}}\right)
$$

\section{Results and Discussion}

\subsection{Thermogravimetric Analysis}

Influence of heating rate: Thermogravimetric (TG) and differential thermogravimetric (DTG) curves for the pyrolysis of the ground rubber sample at heating rates of 5, 10, and $20^{\circ} \mathrm{C} \min ^{-1}$ are shown in Figure 3 a. The ground rubber sample decomposed similarly at the three different heating rates; the thermal degradation started at around $200{ }^{\circ} \mathrm{C}$, and the mass decreased steadily between 300 and $500{ }^{\circ} \mathrm{C}$. Pyrolysis of the ground rubber sample at the different heating rates was mainly complete by $500{ }^{\circ} \mathrm{C}$, above which there is no further weight loss. The pyrolysis residue increased slightly with the increasing heating rate, and it represented an average of $33 \mathrm{wt} . \%$ of the initial weight. The lowest heating rate $\left(5^{\circ} \mathrm{C} \mathrm{min}^{-1}\right)$ provided higher residence time and resulted in a more extended degradation than at higher heating rates. According to DTG curves, the ground rubber sample loses weight in a broad temperature range between 200 and $550{ }^{\circ} \mathrm{C}$ and yields three DTG peaks. This is consistent with the relatively complex chemical composition of tire rubber. According to the previous studies [56-61], the lower temperature between 200 and $300{ }^{\circ} \mathrm{C}$ represents the decomposition of oils, plasticizer, and additives embodied in the tire rubber and the second $\left(300-400{ }^{\circ} \mathrm{C}\right)$ and third $\left(400-500{ }^{\circ} \mathrm{C}\right)$ regions of weight loss represent the decomposition of natural rubber (NB), polybutadene rubber (BR), and polybutadene-styrene rubber (SBR).

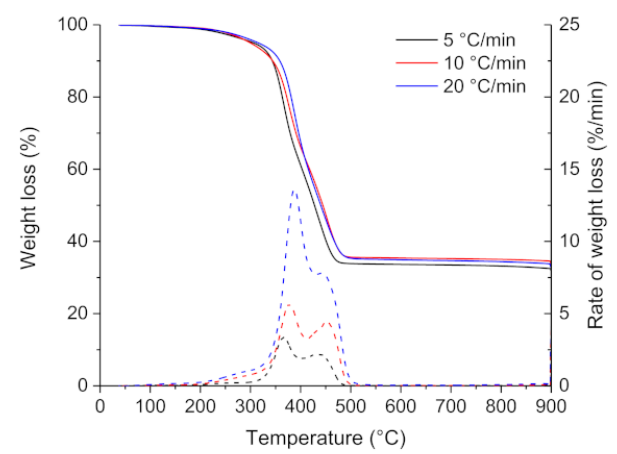

(a)

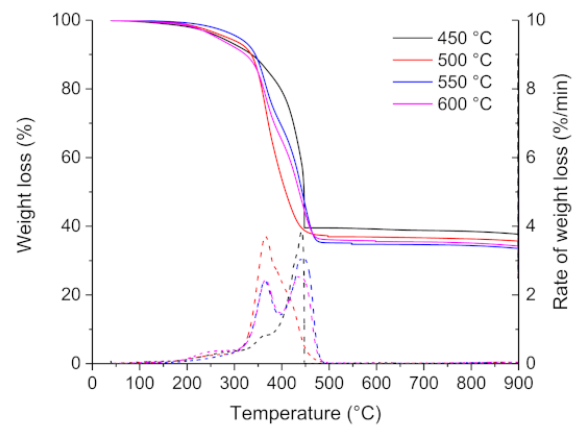

(b)

Figure 3. TG and DTG curves for the pyrolysis of the ground rubber sample at different (a) heating rates and (b) pyrolysis temperatures. 
Proximate analysis data obtained from the pyrolysis of the ground rubber sample at different heating rates are shown in Table 4 . Results showed that the distribution of the different volatile matter, fixed carbon, and ash fractions was roughly unaffected by heating rate. The lowest heating rate $\left(5^{\circ} \mathrm{C} \mathrm{min}^{-1}\right)$ generated the highest volatile matter fraction and the lowest fixed carbon fraction. Pyrolysis at a low heating rate may provide a higher residence time of the sample at the reaction temperature range, which results in greater devolatilization and more release of volatiles.

Table 4. Effect of the heating rate and the pyrolysis temperature on the proximate analysis of the ground rubber sample.

\begin{tabular}{ccccc}
\hline $\begin{array}{c}\text { Heating Rate } \\
\left({ }^{\circ} \mathbf{C} \mathbf{~ m i n}^{-1}\right)\end{array}$ & Volatiles (wt.\%) & $\begin{array}{c}\text { Fixed Carbon } \\
\text { (wt.\%) }\end{array}$ & Ash (wt.\%) & $\begin{array}{c}\text { Char Yield } \\
\text { (wt.\%) }\end{array}$ \\
\hline 5 & 67.8 & 27.5 & 4.7 & 32.2 \\
10 & 65.8 & 31.4 & 2.7 & 34.2 \\
20 & 66.9 & 29.2 & 4.0 & 33.1 \\
\hline Temperature & Volatiles (wt.\%) & $\begin{array}{c}\text { Fixed Carbon } \\
\text { (wt.\%) }\end{array}$ & Ash (wt.\%) & $\begin{array}{c}\text { Char Yield } \\
\text { (wt.\%) }\end{array}$ \\
\hline$\left.{ }^{\circ} \mathbf{C}\right)$ & 60.3 & 26.3 & 13.4 & 39.7 \\
450 & 63.0 & 35.8 & 1.2 & 37.0 \\
500 & 65.2 & 34.0 & 0.8 & 34.8 \\
550 & 64.4 & 30.5 & 5.1 & 35.6 \\
\hline 600 & & &
\end{tabular}

Influence of pyrolysis temperature: TG and DTG curves for the pyrolysis of the ground rubber sample at temperatures of 450,500, 550, and $600^{\circ} \mathrm{C}$ are shown in Figure $3 \mathrm{~b}$. For the four pyrolysis runs, the decomposition occurred in the same temperature range between 200 and $500{ }^{\circ} \mathrm{C}$. The char yield decreased slightly with increasing pyrolysis temperature. Char yields from pyrolysis of the ground rubber sample at temperatures between 450 and $600{ }^{\circ} \mathrm{C}$ were in the 35-40 wt.\% range. This is consistent with the results of other workers $[12,27,62,63]$. The temperatures for which the maximum rate of reaction occurred $\left(\mathrm{T}_{1}\right.$ and $\left.\mathrm{T}_{2}\right)$ are almost identical for the four runs. The char yield decreased as the pyrolysis temperature increased and reached a minimum yield of $34.8 \mathrm{wt} . \%$ at $550{ }^{\circ} \mathrm{C}$ and then increased as the temperature increased from 550 to $600{ }^{\circ} \mathrm{C}$. The minimum yield of char and maximum yield of volatiles at $550{ }^{\circ} \mathrm{C}$ can be attributed to the balance for the competition between the primary pyrolysis reaction and secondary post-cracking reaction.

Proximate analysis (Table 4) for the pyrolysis of the ground rubber sample at different temperatures gave approximately a fixed carbon content between 26 and $36 \mathrm{wt}$. \%, a volatile matter content between 60 and $65 \mathrm{wt} . \%$, and an ash content between 1 and $13 \mathrm{wt} . \%$. The volatile matter and fixed carbon contents increased with the increase in temperature from 450 to $550{ }^{\circ} \mathrm{C}$. The further increase in pyrolysis temperature from 550 to $600{ }^{\circ} \mathrm{C}$ led to a decrease in both volatile matter and fixed carbon yields. Conversely, the increase in pyrolysis temperature was found to have the opposite effect on the evolution of ash content; the ash content underwent a remarkable decrease during the increase in temperature from 450 to $550{ }^{\circ} \mathrm{C}$, and it increased considerably at $600^{\circ} \mathrm{C}$. The significant change in ash content can be explained by the evolution of the chemical composition of inorganic matter, initially present in the tire, upon increasing the pyrolysis temperature. Tire-rubber is mainly composed of natural and/or synthetic rubber, sulfur, and other mineral additives, such as zinc oxide. During pyrolysis, the inorganic species initially present in tires are prone to volatilization, decomposition, and recombination, or they stay stable as the organic component of tire decomposes. The occurrence of these reactions is mainly determined by the pyrolysis temperature and the chemical composition of the sample taken for analysis (sampling).

The present trend of ash content evolution was comparable with another tested ground rubber sample with an average particle size of $0.2-0.63 \mathrm{~mm}$. However, this sample showed lower variations in ash content upon the increase in the pyrolysis temperature. These results indicated that the ground rubber sample with large particle size exhibited 
constitutional heterogeneity, which means that the particles do not have a strictly identical chemical composition.

\subsection{Product Yields}

Effect of pyrolysis temperature on product yields: The product distributions from pyrolysis of the ground rubber sample at different temperatures are presented in Table 5. The pyrolysis product distribution did not change significantly as the temperature increased from 450 to $550{ }^{\circ} \mathrm{C}$. The volatiles (liquids and gases) yields are almost constant at a value of about 62 wt.\%. The solid yield remained essentially constant with a mean of $38 \mathrm{wt} . \%$. The data suggested that the primary pyrolysis reaction was already completed in the pilot-scale fixed-bed reactor at a temperature of $450^{\circ} \mathrm{C}$. The yield of pyrolytic oil increased from 29.7 to $34.2 \mathrm{wt} . \%$, whereas the gas yield decreased with increasing temperature from 450 to $550{ }^{\circ} \mathrm{C}$. Similar results have been obtained by other researchers [12,64-66]. Rodriguez et al. [12] carried out pyrolysis experiments on 2-3 cm wide cross-sections of car tires at 300, 400, 500, 600 , and $700{ }^{\circ} \mathrm{C}$ at a heating rate of $15^{\circ} \mathrm{C} \mathrm{min}{ }^{-1}$. The authors have found that pyrolysis was incomplete at 300 and $400{ }^{\circ} \mathrm{C}$, and the solid yield dropped by $32 \mathrm{wt} . \%$ over the $300-500{ }^{\circ} \mathrm{C}$ temperature range. However, no significant influence of temperature on solid yields was observed over $500{ }^{\circ} \mathrm{C}$, and the solid yields obtained at 500,600, and $700{ }^{\circ} \mathrm{C}$ were around 44 wt.\%. In another study, Li et al. [64] carried out pilot-scale pyrolysis experiments on 13-15 mm shredded scrap tires using a continuous pyrolytic rotary kiln reactor and varying the pyrolysis temperature from 450 to $650{ }^{\circ} \mathrm{C}$. The authors have found that the solid char yield remained essentially constant with a mean of $39.8 \mathrm{wt} \%$, except for the relatively high value of $43.9 \mathrm{wt}$. \% at a temperature of $450{ }^{\circ} \mathrm{C}$, which was higher than the data in this study. The char yield in the pilot-scale static bed reactor was compared with that of other reactor processes in Table 5 . The products recovered by the different pyrolysis processes in the 400-600 ${ }^{\circ} \mathrm{C}$ temperature range were 30.0-55.9 wt.\% pyrolytic char, $24.8-65.0 \mathrm{wt}$ \% oil, and 30.0-55.9 wt.\% gas fraction. The data suggest that the pyrolytic char yield is not sensitive to the heating rate, behavior that differs greatly from the pyrolysis of biomass, for which the biochar yield strongly depends on the heating rate [67]. Conversely, the oil yield varied greatly for the different reaction conditions.

Table 5. Comparison of product yields derived from ground rubber pyrolysis reported in the literature with the results of the present study.

\begin{tabular}{|c|c|c|c|c|c|}
\hline Reactor Type & $\begin{array}{c}\text { Temperature } \\
\left({ }^{\circ} \mathrm{C}\right)\end{array}$ & $\begin{array}{l}\text { Solid Yield } \\
\text { (wt. } \%)\end{array}$ & $\begin{array}{l}\text { Liquid Yield } \\
\text { (wt. \%) }\end{array}$ & $\begin{array}{c}\text { Gas Yield } \\
\text { (wt. } \%)\end{array}$ & Reference \\
\hline \multirow{3}{*}{$\begin{array}{l}\text { Pilot-scale } \\
\text { static bed }\end{array}$} & 450 & 38.1 & 29.7 & 32.2 & \multirow{3}{*}{ This study } \\
\hline & 500 & 37.8 & 30.5 & 31.7 & \\
\hline & 550 & 37.8 & 34.2 & 28.0 & \\
\hline \multirow{3}{*}{$\begin{array}{l}\text { Laboratory- } \\
\text { scale static } \\
\text { bed batch }\end{array}$} & 400 & 55.9 & 24.8 & 19.3 & \multirow{3}{*}{ [12] } \\
\hline & 500 & 44.8 & 38.0 & 17.2 & \\
\hline & 600 & 44.2 & 38.2 & 17.5 & \\
\hline \multirow{3}{*}{$\begin{array}{l}\text { Pilot-scale } \\
\text { continuous } \\
\text { rotary kiln }\end{array}$} & 450 & 43.9 & 43.0 & 13.1 & \multirow{3}{*}[64]{} \\
\hline & 500 & 41.3 & 45.1 & 13.6 & \\
\hline & 550 & 39.9 & 44.6 & 15.5 & \\
\hline \multirow{3}{*}{$\begin{array}{l}\text { Pilot-scale } \\
\text { static bed } \\
\text { batch }\end{array}$} & 450 & 37.4 & 58.1 & 4.5 & \multirow{3}{*}{ [65] } \\
\hline & 500 & 38.3 & 56.2 & 5.5 & \\
\hline & 600 & 38.0 & 53.1 & 8.9 & \\
\hline \multirow{3}{*}{$\begin{array}{l}\text { Pilot-scale } \\
\text { fluidized bed }\end{array}$} & 500 & 30.0 & 65.0 & 5.0 & \multirow{3}{*}{ [66] } \\
\hline & 550 & 34.0 & 57.0 & 9.2 & \\
\hline & 600 & 40.0 & 51.0 & 9.1 & \\
\hline
\end{tabular}

Effect of activation method on activated char yields: The yields of activated chars are presented in Table 6. Data reported in the literature are also given for comparison. Activation of the char at $700{ }^{\circ} \mathrm{C}$ with $\mathrm{KOH}$ yields 70 wt. $\%$ of activated char. Activation 
of the char at $850{ }^{\circ} \mathrm{C}$ with $\mathrm{CO}_{2}$ yields $87 \mathrm{wt} . \%$ of activated char. A large drop in the yield from 70 to $57 \mathrm{wt}$.\% was observed when the chemically activated char was subjected to a subsequent physical activation. Work reported elsewhere had shown that the activation treatment, under very close conditions, yields $63-93 \mathrm{wt} \%$ of activated char. Indeed, Acosta et al. [68] obtained chemically activated char yields of 81 and $74 \mathrm{wt} . \%$ at activation temperatures of 700 and $750{ }^{\circ} \mathrm{C}$, respectively. Ucar et al. [69] reported an activated char yield of $93 \mathrm{wt.} \%$ at a temperature of $900{ }^{\circ} \mathrm{C}$ while Helleur et al. [40] and Danmaliki et al. [70] obtained activated char yields of 88 and $62 \mathrm{wt} . \%$ at activation temperatures of 875 and $850^{\circ} \mathrm{C}$, respectively.

Table 6. Comparison of activated carbon yield reported in the literature with those obtained in the present study.

\begin{tabular}{|c|c|c|c|c|c|}
\hline Rubber Size (mm) & $\begin{array}{c}\text { Temperature }\left({ }^{\circ} \mathrm{C}\right) / \\
\text { Heating Rate }\left({ }^{\circ} \mathrm{C} \text { min }^{-1}\right)\end{array}$ & $\begin{array}{l}\text { Residence Time } \\
\text { (min) }\end{array}$ & $\begin{array}{l}\text { Activating Agent/ } \\
\text { Weight Ratio }\end{array}$ & $\begin{array}{l}\text { Activated Carbon } \\
\text { Yield (wt. } \% \text { ) }\end{array}$ & Reference \\
\hline $1.5-4$ & $700 / 5$ & 180 & $\mathrm{KOH} /(1: 3)$ & 70 & Present study \\
\hline $1.5-4$ & $850 / 5$ & 120 & $\mathrm{CO}_{2}$ & 87 & Present study \\
\hline $1.5-4$ & $700 / 5$ and $700 / 5$ & 180 and 20 & $\mathrm{KOH} /(1: 3)$ and $\mathrm{CO}_{2}$ & 57 & Present study \\
\hline $1.1-1.7$ & $700 / 3$ & 60 & $\mathrm{KOH} /(1: 2)$ & 81 & [68] \\
\hline $1.1-1.7$ & $750 / 3$ & 60 & $\mathrm{KOH} /(1: 4)$ & 74 & [68] \\
\hline $1.5-2.0$ & 900/N.M & 120 & $\mathrm{CO}_{2}$ & 93 & [69] \\
\hline N.M & $875 / 20$ & 100 & $\mathrm{CO}_{2}$ & 88 & [40] \\
\hline $0.5-1$ & 850/N.M & 120 & $\mathrm{CO}_{2}$ & 62 & [70] \\
\hline
\end{tabular}

\subsection{Characterization of the Chars}

The thermogravimetric analysis of BC450, BC500, and BC550 char samples obtained through the pilot-scale pyrolysis experiments are shown in Figure 4. The TG curves of the three char samples showed a slight weight loss of 1-2 wt.\% in the temperature range of $35-120{ }^{\circ} \mathrm{C}$, which is due to moisture desorption. A very slight weight loss was observed in the BC550 thermogram with an increase in temperature to $900{ }^{\circ} \mathrm{C}$, while a higher weight loss was observed for BC450 and BC500 samples between 400 and $900{ }^{\circ} \mathrm{C}$, which can be ascribed to the incomplete pyrolysis of the ground rubber.

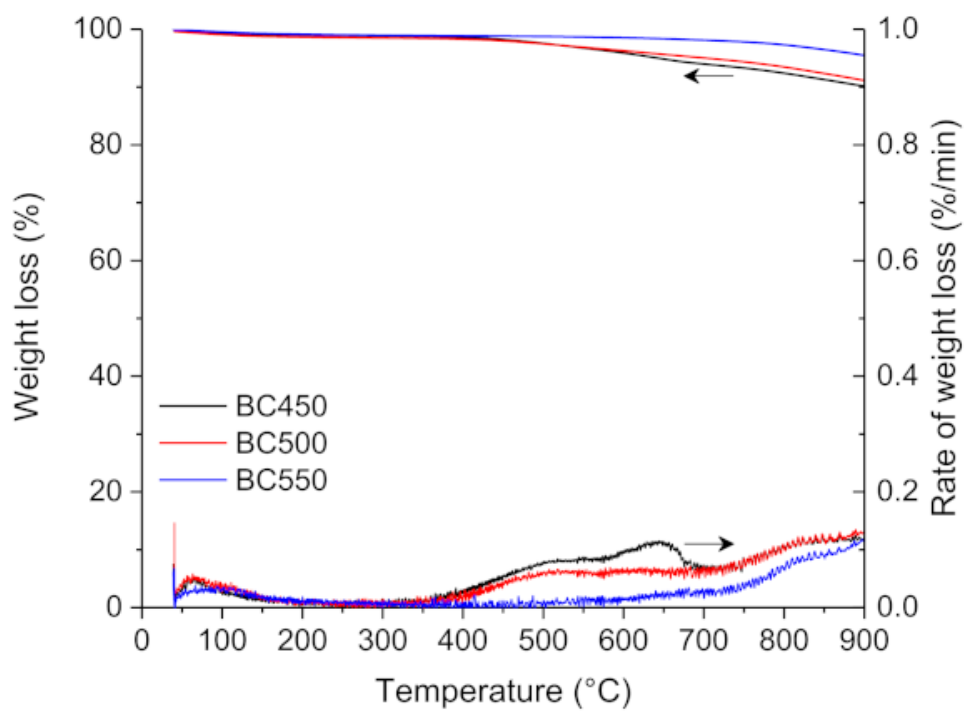

Figure 4. TG and DTG curves for the pyrolysis of the ground rubber-based chars.

Table 7 illustrates the proximate analysis of the ground rubber-based chars. Fixed carbon content ranged from 78 to $86.5 \mathrm{wt} \%$, the volatile matter content ranged from 4.1 to $9.3 \mathrm{wt} . \%$, and the ash content ranged from 9.4 to $12.7 \mathrm{wt}$.\%. The volatile matter decreased with increasing pyrolysis temperature, and this can be attributed to the promoted devolatilization process with an increase in pyrolysis temperature from 450 to $550{ }^{\circ} \mathrm{C}$. The 
high ash content of ground rubber-based biochar originated from the presence of high amounts of inorganic materials, such as zinc and copper, and their concentration in the final char via the pyrolysis process.

Table 7. Physicochemical properties of the ground rubber-based chars.

\begin{tabular}{|c|c|c|c|}
\hline & BC450 & BC500 & BC550 \\
\hline \multicolumn{4}{|l|}{ Proximate Analysis (wt. $\%$, dry basis) } \\
\hline Total volatile matter & 9.3 & 8.1 & 4.1 \\
\hline Fixed carbon & 78.0 & 79.5 & 86.5 \\
\hline Ash & 12.7 & 12.5 & 9.4 \\
\hline \multicolumn{4}{|l|}{ Elemental analysis * (wt.\%, dry basis) } \\
\hline $\mathrm{C}$ & 86.69 & 88.05 & 90.90 \\
\hline $\mathrm{O}$ & 6.41 & 5.59 & 4.10 \\
\hline $\mathrm{Mg}$ & 0.10 & 0.11 & 0.12 \\
\hline $\mathrm{Al}$ & 0.11 & 0.11 & 0.22 \\
\hline $\mathrm{Si}$ & 2.81 & 2.05 & 0.63 \\
\hline $\mathrm{P}$ & 0.02 & 0.02 & 0.02 \\
\hline S & 1.66 & 1.66 & 1.67 \\
\hline $\mathrm{Cl}$ & 0.02 & 0.04 & 0.04 \\
\hline $\mathrm{K}$ & 0.04 & 0.04 & 0.04 \\
\hline $\mathrm{Ca}$ & 0.07 & 0.04 & 0.11 \\
\hline $\mathrm{Fe}$ & 0.04 & 0.05 & 0.04 \\
\hline $\mathrm{Co}$ & 0.03 & 0.03 & 0.05 \\
\hline $\mathrm{Zn}$ & 1.92 & 2.15 & 1.95 \\
\hline $\mathrm{Br}$ & 0.06 & 0.06 & 0.06 \\
\hline \multicolumn{4}{|l|}{ Textural Properties } \\
\hline BET surface area $\left(\mathrm{N}_{2}\right)\left(\mathrm{m}^{2} \mathrm{~g}^{-1}\right)$ & 81.87 & 85.88 & 71.41 \\
\hline Total pore volume $\left(\mathrm{N}_{2}\right)\left(\mathrm{cm}^{3} \mathrm{~g}^{-1}\right)$ & 0.55 & 0.58 & 0.53 \\
\hline Average pore width ${ }^{* *}\left(\mathrm{~N}_{2}\right)(\mathrm{nm})$ & 27.16 & 34.05 & 34.35 \\
\hline BET surface area $\left(\mathrm{CO}_{2}\right)\left(\mathrm{m}^{2} \mathrm{~g}^{-1}\right)$ & 57.08 & 76.15 & 63.58 \\
\hline ID/IG ratio & 0.63 & 0.89 & 1.30 \\
\hline
\end{tabular}

Table 7 lists the elemental analysis of the ground rubber-based chars at the different pyrolysis temperatures. The carbon content of the char samples ranged from 87 to $91 \mathrm{wt} . \%$, which makes these materials good candidates for activated carbon production. The carbon content appears to be high when compared with biomass-based biochar and agricultural waste-based biochar [71,72]. The high carbon content is attributed to the application of carbon black as a reinforcing filler in rubber elastomers manufacturing [73]. Silicon, sulfur, and zinc constituted the major inorganic elements found in the char samples. These results are expected since $\mathrm{Si}, \mathrm{S}$, and $\mathrm{Zn}$ oxide are widely used as a reinforcing filler in rubber elastomers manufacturing, in addition to carbon black. The presence of sulfur can promote the adsorption of certain pollutants, such as heavy metals, onto the carbonaceous materials. Many studies have shown positive effects of sulfur groups on the adsorption properties of activated carbons [74-76]. No significant change was detected in the mineral composition, except silicon, between the chars produced at different pyrolysis temperatures. Silicon content showed a significant decrease from 2.81 to $0.63 \mathrm{wt} . \%$ when the pyrolysis temperature increased from 450 to $550{ }^{\circ} \mathrm{C}$.

The $\mathrm{N}_{2}$ adsorption-desorption isotherms of the ground rubber-based chars produced at different pyrolysis temperatures are shown in Figure 5. All the char samples gave type (IV) isotherms, characteristic of mesoporous solids according to the IUPAC classification [77], with H1-type hysteresis loops. The BET surface area, total pore volume, and average pore width of the char samples are listed in Table 7. The BET surface area of the char samples varied from 71.41 (for $\mathrm{BC} 550$ ) to $85.88 \mathrm{~m}^{2} \mathrm{~g}^{-1}$ (for $\mathrm{BC} 500$ ). The pore volume ranged between 0.53 and $0.58 \mathrm{~cm}^{3} \mathrm{~g}^{-1}$ and followed a similar variation trend to the surface areas. All the 
pores were in the meso-range, and the average pore width varied from 34.05 to $36.61 \mathrm{~nm}$. The BC500 sample presented the highest surface area, as well as the highest pore volume. The textural properties of the produced chars from ground rubber are similar to those recorded by other authors [25], and they do not show any great variations with the increase in pyrolysis temperature. Compared to other carbonaceous materials used as adsorbents, rubber-based chars with low surface areas cannot be used as an efficient adsorbent for the removal of pollutants. Therefore, an activation treatment should be applied to develop the porosity in the structure of the produced chars.
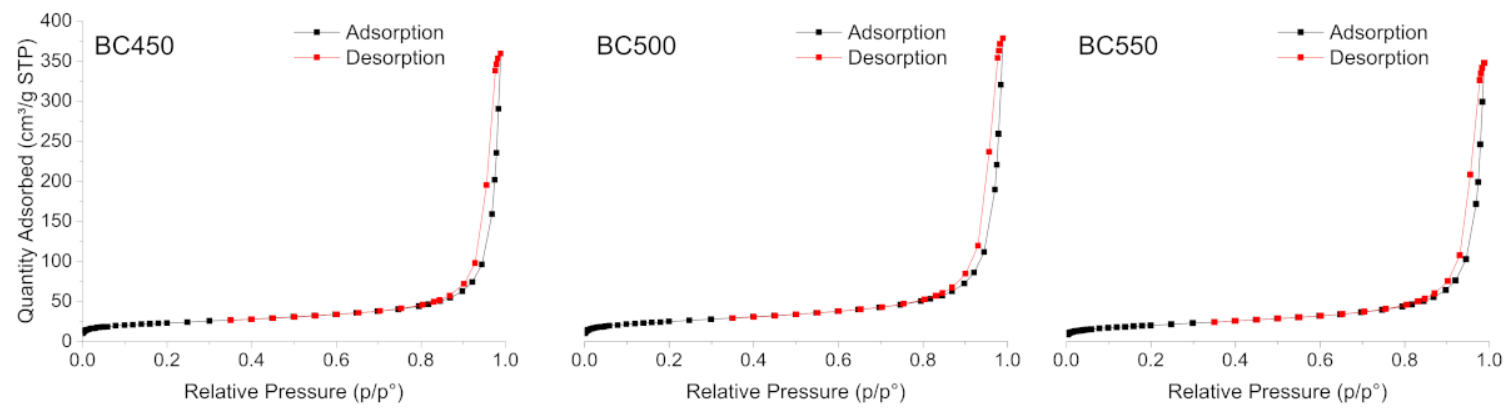

Figure 5. $\mathrm{N}_{2}$ adsorption-desorption isotherms of the ground rubber-based chars.

The SEM images, at a magnification of 50,000 $\times$ and the EDX elemental maps of the ground rubber-based chars are given in Figure 6. SEM images revealed dense and rough surfaces without notable cracks or pores. Amorphous and quasi-spherical clusters of nanosized particles can be seen, which could be attributed to the organic matter. The surface morphology in overall samples seemed not to be affected by increases in the pyrolysis temperature. EDX analyses of the char samples indicated the presence of various mineral elements, mainly S, $\mathrm{Zn}, \mathrm{Si}, \mathrm{Co}, \mathrm{Mg}, \mathrm{Ca}, \mathrm{Al}, \mathrm{K}$, and $\mathrm{P}$. The above results are in good agreement with the results obtained from XRF. For the BC450 and BC550 samples, lumps of zinc and sulfur grains existed at the same locations, which suggests that they occur in the form of zinc sulfide. Zinc sulfide might be produced by the reaction between the zinc oxide and sulfur contained in tires [63].
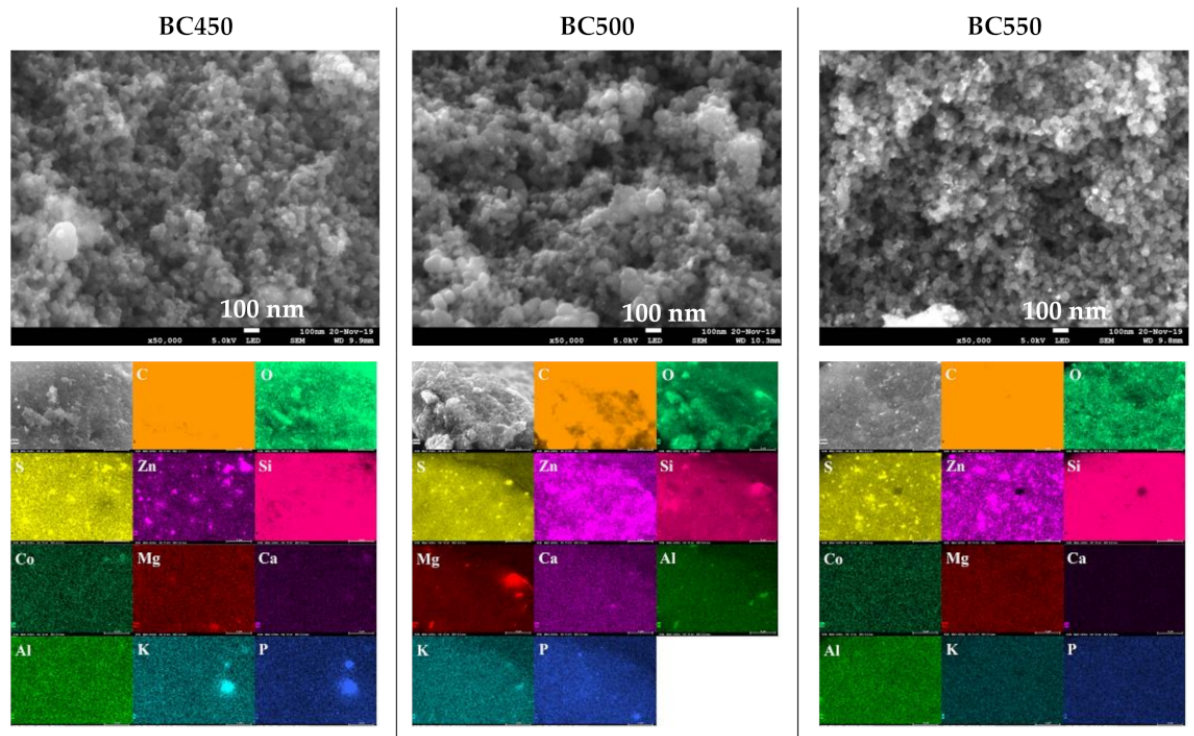

Figure 6. SEM images and elemental distribution maps of the ground rubber-based chars.

The XRD patterns of the ground rubber-based chars are shown in Figure 7. The XRD patterns showed the presence of rhombohedral $\mathrm{CaCO}_{3}$ (JCPDS 01-078-4614), hexagonal $\mathrm{ZnO}$ (JCPDS 01-078-2585), and rhombohedral ZnS (JCPDS 01-089-2203). ZnO and sulfur 
present in the tires may react during pyrolysis to form $\mathrm{ZnS}$. The diffraction peaks corresponding to the $\mathrm{CaCO}_{3}$ phase lose their intensity during an increase in the pyrolysis temperature from 450 to $550{ }^{\circ} \mathrm{C}$, which is probably due to the decomposition reaction of calcium carbonate. The intensity of the baseline of the diffractogram at $2 \theta \approx 25^{\circ}$ is mainly related to the presence of non-aromatic amorphous carbon in the char samples [78].

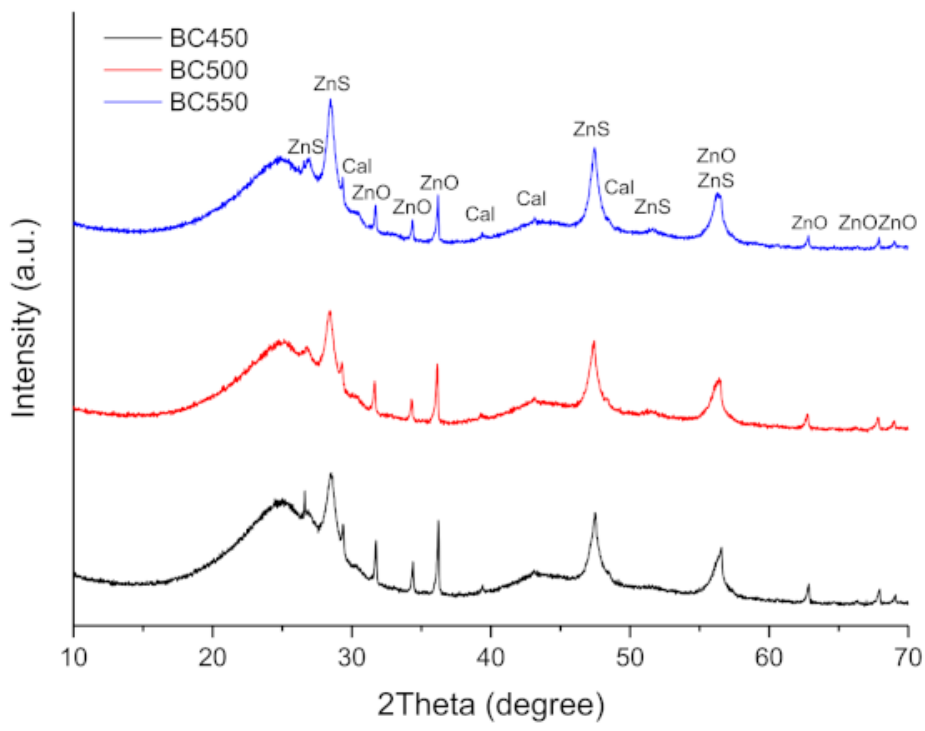

Figure 7. XRD patterns of the ground rubber-based chars.

The Raman spectra (data are not shown) of the different chars exhibited two relatively broad Raman bands at around $1350-1385 \mathrm{~cm}^{-1}$ and $1585-1590 \mathrm{~cm}^{-1}$. These bands correspond to the D-band and G-band, respectively. The G-band and D-band correspond to graphite and defects in the graphite carbon structure, respectively [79]. Structural parameters, such as the intensity ratios between the D- and G-bands (ID/IG ratio) for the three char samples were determined. The ID/IG ratio (see Table 7) of the ground rubber-based chars showed an increase with increasing pyrolysis temperature from 450 to $550^{\circ} \mathrm{C}$. The observed results suggest that the variation of ID/IG ratio in the studied temperature range is mainly related to the development of amorphous carbon, and apparently not to graphitization. Increasing the pyrolysis temperature above $550{ }^{\circ} \mathrm{C}$ might result in a decrease in ID/IG ratio due to the increase in the degree of graphitization (char evolution structure from the amorphous carbon to an organized carbon).

\subsection{Characterization of the Activated Chars}

Table 8 lists the concentrations of carbon, oxygen, and mineral elements in the activated chars. The mineral compositions of the chemically activated char were different from those determined for the non-activated chars. $\mathrm{Al}, \mathrm{Si}, \mathrm{S}$, and $\mathrm{Zn}$ contents were lower in the chemically activated chars, and $\mathrm{K}$ and $\mathrm{Mg}$ slightly increased. This suggests that chemical activation with $\mathrm{KOH}$ could be considered an indirect demineralization treatment that decreases the mineral impurities in char, which will improve the properties and market value of the activated chars. The very low mineral content of the rest of the analyzed elements is the reason for not seeing any significant effects from the activation treatments. The mineral contents in the $\mathrm{CO}_{2}$-activated char were in the same range as found in non-activated char. 
Table 8. Physicochemical properties of the activated chars.

\begin{tabular}{cccc}
\hline Elemental Analysis (wt.\%, Dry Basis) & CA-BC450 & PA-BC450 & CPA-BC450 \\
\hline $\mathrm{C}$ & 95.96 & 86.90 & 96.13 \\
$\mathrm{O}$ & 1.70 & 6.36 & 1.60 \\
$\mathrm{Mg}$ & 0.16 & 0.07 & 0.17 \\
$\mathrm{Al}$ & 0.27 & 0.48 & 0.24 \\
$\mathrm{Si}$ & 0.64 & 3.11 & 0.59 \\
$\mathrm{P}$ & 0.00 & 0.02 & 0.00 \\
$\mathrm{~S}$ & 0.26 & 1.23 & 0.22 \\
$\mathrm{Cl}$ & 0.02 & 0.00 & 0.00 \\
$\mathrm{~K}$ & 0.73 & 0.04 & 0.80 \\
$\mathrm{Ca}$ & 0.11 & 0.08 & 0.11 \\
$\mathrm{Fe}$ & 0.04 & 0.06 & 0.05 \\
$\mathrm{Co}$ & 0.03 & 0.02 & 0.03 \\
$\mathrm{Cu}$ & 0.00 & 0.01 & 0.01 \\
$\mathrm{Zn}$ & 0.00 & 1.60 & 0.00 \\
$\mathrm{Br}$ & 0.01 & 0.01 & 0.00 \\
$\mathrm{Zr}$ & 0.02 & 0.01 & 0.01 \\
\hline Textural Properties & & & \\
\hline BET surface area $\left(\mathrm{N}_{2}\right)\left(\mathrm{m}^{2} \mathrm{~g}^{-1}\right)$ & 493.75 & 164.33 & 490.28 \\
Total pore volume $\left(\mathrm{N}_{2}\right)\left(\mathrm{cm}^{3} \mathrm{~g}^{-1}\right)$ & 0.48 & 0.72 & 0.50 \\
Average pore width $\left(\mathrm{N}_{2}\right)\left(\mathrm{nm}^{-1}\right.$ & 14.97 & 35.12 & 13.35 \\
BET surface area $\left(\mathrm{CO}_{2}\right)\left(\mathrm{m}^{2} \mathrm{~g}^{-1}\right)$ & 308.54 & 117.69 & 279.33 \\
\hline ID/IG Ratio & 1.41 & 1.44 & 1.40 \\
\hline
\end{tabular}

Figure 8 shows the $\mathrm{N}_{2}$ adsorption-desorption isotherms of the activated chars obtained through the different activation methods. The development of micropores and mesopores for the chemically activated chars can be clearly deduced by the shape of the isotherms. CA-BC450 and CPA-BC450 samples exhibited isotherms of mixed types IV and I, with H4-type hysteresis loops that can be associated with the presence of narrow, slit-like pores. These isotherms are characteristic of adsorbents containing both micropores and mesopores, according to the IUPAC classification [77]. The $\mathrm{N}_{2}$ adsorption-desorption isotherm of the PA-BC450 sample is of mixed types II and I, typical for macroporous and microporous adsorbents, with an H3-type hysteresis loop related to aggregates of plate-like particles, giving rise to slit-shaped pores. The textural properties of the activated chars are summarized in Table 8. The activated chars exhibited a larger surface area than that of the non-activated char. The BET surface areas of the $\mathrm{KOH}$-activated char according to $\mathrm{N}_{2}$ and $\mathrm{CO}_{2}$ adsorption measurements were 494 (six times higher than that of the non-activated char) and $309 \mathrm{~m}^{2} \mathrm{~g}^{-1}$, respectively. The $\mathrm{CO}_{2}$-activated char possesses a BET surface area of $164 \mathrm{~m}^{2} \mathrm{~g}^{-1}$ according to $\mathrm{N}_{2}$ adsorption measurements (two times higher than that of the non-activated char) and $117 \mathrm{~m}^{2} \mathrm{~g}^{-1}$ according to $\mathrm{CO}_{2}$ adsorption measurements. The BET surface areas, determined by $\mathrm{N}_{2}$ and $\mathrm{CO}_{2}$ adsorption measurements, of the char activated by both $\mathrm{KOH}$ and $\mathrm{CO}_{2}$ were in the same range as the surface areas of the char activated only by $\mathrm{KOH}$. The results clearly demonstrated that the activation process is efficient for increasing the surface area and the development of new pores with different widths and volumes. A comparison of BET surface areas of activated chars produced in the present study with those reported in the literature is presented in Table 9. The surface areas of the produced activated chars are comparable with those reported in the literature. Activated chars with surface areas in the range of $166-405 \mathrm{~m}^{2} \mathrm{~g}^{-1}$ have been obtained from ground rubber by chemical activation using $\mathrm{KOH}$ as an activating agent. $\mathrm{CO}_{2}$-activated char with surface areas in the range of $91-399 \mathrm{~m}^{2} \mathrm{~g}^{-1}$ were also obtained. 


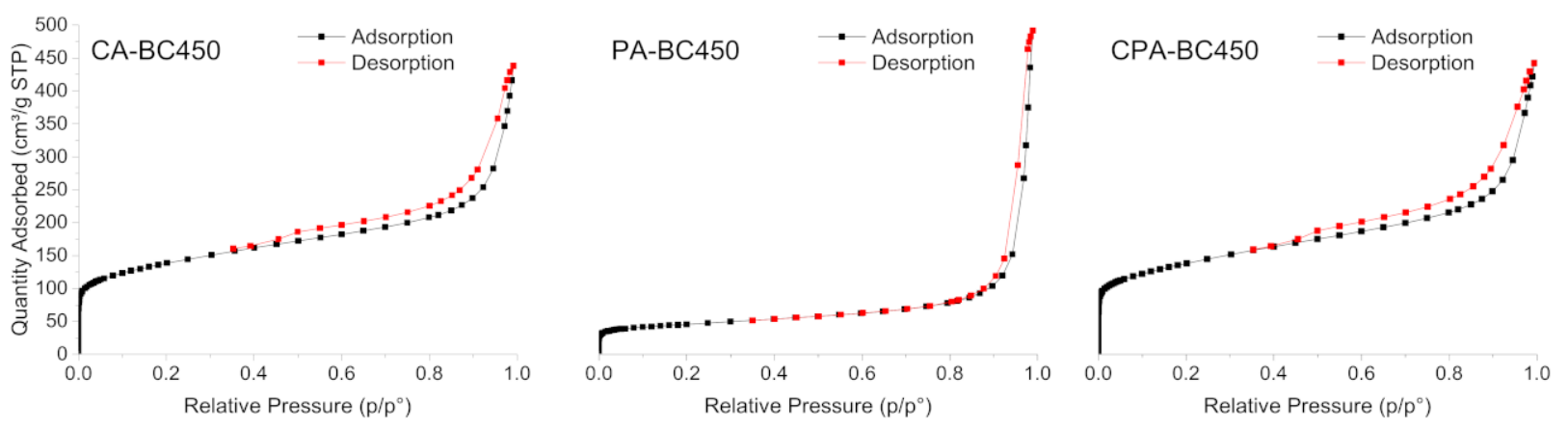

Figure 8. $\mathrm{N}_{2}$ adsorption-desorption isotherms of the activated chars.

Table 9. Comparison of BET surface areas of activated chars produced in the present study with those reported in the literature.

\begin{tabular}{|c|c|c|c|c|c|}
\hline Rubber Size (mm) & $\begin{array}{c}\text { Activation Tempera- } \\
\text { ture }\left({ }^{\circ} \mathrm{C}\right) / \text { Heating } \\
\text { Rate }\left({ }^{\circ} \mathrm{C} \mathrm{min}{ }^{-1}\right)\end{array}$ & $\begin{array}{l}\text { Residence Time } \\
\text { (min) }\end{array}$ & $\begin{array}{c}\text { Activating } \\
\text { Agent/Weight Ratio }\end{array}$ & $\begin{array}{c}\text { BET Surface } \\
\left(\mathrm{m}^{2} \mathrm{~g}^{-1}\right) / M_{\text {Mesopore }} \\
\text { Volume }\left(\mathrm{cm}^{3} \mathrm{~g}^{-1}\right)\end{array}$ & Reference \\
\hline $1.5-4$ & - & - & - & $81 / 0.55$ & This study \\
\hline $1.5-4$ & $700 / 5$ & 180 & $\mathrm{KOH} /(1: 3)$ & $494 / 0.48$ & This study \\
\hline $1.5-4$ & $850 / 5$ & 120 & $\mathrm{CO}_{2}$ & $164 / 0.72$ & This study \\
\hline $1.5-4$ & $700 / 5$ and $700 / 5$ & 180 and 20 & $\mathrm{KOH} /(1: 3)$ and $\mathrm{CO}_{2}$ & $490 / 0.50$ & This study \\
\hline $1.1-1.7$ & $700 / 3$ & 60 & $\mathrm{KOH} /(1: 2)$ & $166 / 0.56$ & [68] \\
\hline $1.5-2$ & $700 / 20$ & 120 & $\mathrm{KOH} /(1: 3)$ & $170 / 0.69$ & [71] \\
\hline $1.1-1.7$ & $750 / 3$ & 60 & $\mathrm{KOH} /(1: 4)$ & $405 / 0.61$ & [68] \\
\hline $1.5-2.0$ & 900/N.M & 120 & $\mathrm{CO}_{2}$ & 91/N.M & [69] \\
\hline N.M & $875 / 20$ & 100 & $\mathrm{CO}_{2}$ & 239/N.M & [40] \\
\hline $0.5-1$ & 850/N.M & 120 & $\mathrm{CO}_{2}$ & $399 / 0.26$ & [70] \\
\hline
\end{tabular}

The SEM images at two magnifications $(5000 \times$ and $100,000 \times)$ and elemental distribution maps of the activated chars are given in Figure 9. The SEM images of the $\mathrm{CO}_{2}$-activated chars revealed dense and planar surfaces without notable cracks or pores. The SEM micrographs of the char activated by $\mathrm{KOH}$ and by both $\mathrm{KOH}$ and $\mathrm{CO}_{2}$ showed pits and hollows, as well as sharply defined cliffs denoted by curved lines. It is evident that chemical activation led to a significant surface topographical change of the char, which may result in increased adsorption capacity. Examination of SEM micrographs at high magnification $(100,000 \times)$ shows that activated chars have the same morphology as those of non-activated char. Indeed, quasi-spherical clusters of nano-sized particles have been observed in all samples. Elemental mapping images showed uniform and homogenous distribution of mineral elements on the surfaces of the activated chars.
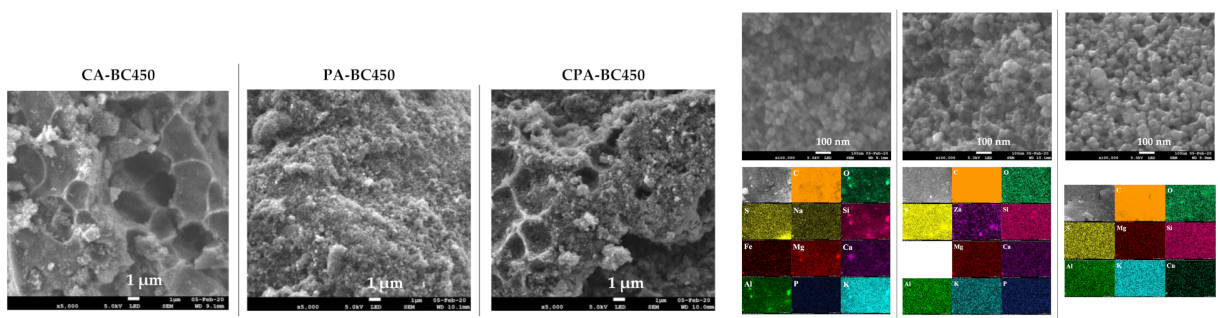

Figure 9. SEM images and elemental distribution maps of the activated chars.

The $D$ and $G$ bands were in the expected regions of $1350-1385 \mathrm{~cm}^{-1}$ and $1585-1590 \mathrm{~cm}^{-1}$, respectively (data are not shown). The ID/IG ratios, determined from the Raman spectra, are listed in Table 8 . The activated chars exhibited comparable band intensity ratios. An increase in band intensity ratio was observed after the activation process. 
The final $\mathrm{pH}$ values $\left(\mathrm{pH}_{\mathrm{f}}\right)$ of the filtrates were plotted against the initial $\mathrm{pH}$ values of the prepared solution $\left(\mathrm{pH}_{\mathrm{i}}\right)$ to determine the surface character of the activated chars, acidic or basic. The results (Figure 10) show that most of the $\mathrm{pH}_{\mathrm{f}}=\mathrm{f}\left(\mathrm{pH}_{\mathrm{i}}\right)$ curves of the activated chars are situated above the middle diagonal line $\left(\mathrm{pH}_{\mathrm{i}}=\mathrm{pH}_{\mathrm{f}}\right)$, indicating the basic character of their surface (negative surface charge). In general, the acidic character of carbon surfaces is linked to the presence of oxygen surface complexes or oxygen functionalities, such as carboxyl, lactones, and phenol, while the basic character is associated with the presence of oxygen atoms forming basic functional groups, such as pyrene, chromene, quinone or with the presence of $\mathrm{p}$ electrons in the graphene structure [72]. The $\mathrm{pH}_{\mathrm{PZC}}$ (the $\mathrm{pH}$ at which the surface charge of the material is zero) of the BC450 and PA-BC450 samples was 8, while the $\mathrm{pH}_{\mathrm{PZC}}$ of the CA-BC450 and CPA-BC450 samples was 11.

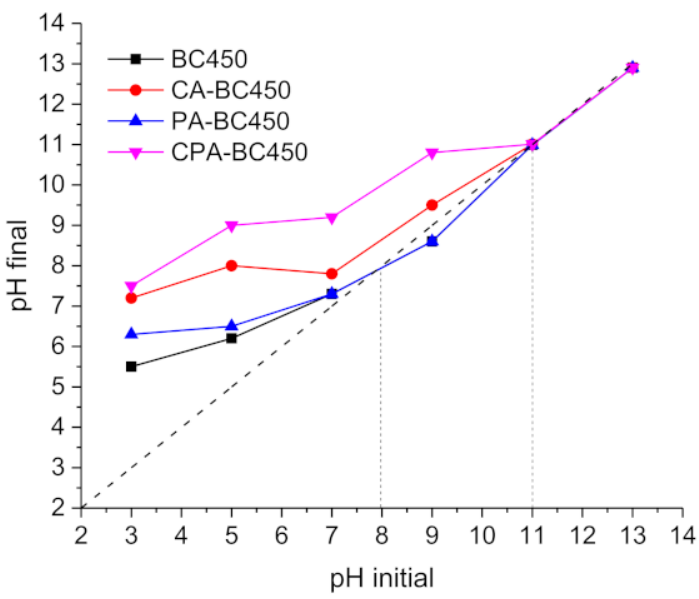

Figure 10. The $\mathrm{pH}$ of the point of zero charge $\left(\mathrm{pH}_{\mathrm{PZC}}\right)$ of the activated chars.

\subsection{Adsorption Tests}

Atrazine or ibuprofen adsorption capacities of the different adsorbents were calculated using Equation (4), and the adsorption isotherms at room temperature are shown in Figure $11 \mathrm{a}, \mathrm{c}$, respectively. As it can be observed, the untreated char and the $\mathrm{CO}_{2}$-activated char exhibited very low adsorption capacities for the two adsorbates, while the $\mathrm{KOH}-$ activated char and $\mathrm{KOH}-\mathrm{CO}_{2}$-activated char showed higher adsorption capacities for both adsorbates. The adsorption capacities of these two activated chars increased successively as the adsorbate's concentration increased; however, saturation was not reached under the studied concentration range. The experimental data for ibuprofen adsorption on the different materials produced in this work did not follow a conventional evolution as expected. Several assumptions can be made to explain this phenomenon, such as interaction with surface of the flask, partial degradation, or low interaction with the adsorbent.

Figure $11 \mathrm{~b}$ shows the atrazine removal efficiency as a function of the initial concentration for the different adsorbents. Upon increasing the atrazine initial concentration from 5 to $20 \mathrm{mg} \mathrm{L}^{-1}$, the atrazine removal efficiency of the CA-BC450 and CPA-BC450 samples increased slightly and reached its maximum (around 90\% for CA-BC450 sample and 95\% for CPA-BC450 sample) at an initial concentration of $10 \mathrm{mg} \mathrm{L}^{-1}$, and upon that value the atrazine removal efficiency decreased from 90 to $76 \%$ for CA-BC450 and from 95 to $86 \%$ for CPA-BC450. Using a BC450 or PA-BC450 sample instead, the atrazine removal was considerably lower, and it increased when the initial concentration of atrazine increased from 8 to $28 \%$ for the BC 450 sample and from 0 to $21 \%$ for the PA-BC 450 sample.

Figure 11d shows the ibuprofen removal efficiency as a function of the initial concentration for the different adsorbents. The removal efficiency of ibuprofen for the different adsorbents was found considerably lower than that of atrazine, and a higher removal efficiency was found for CA-BC450 and CPA-BC450 samples. 


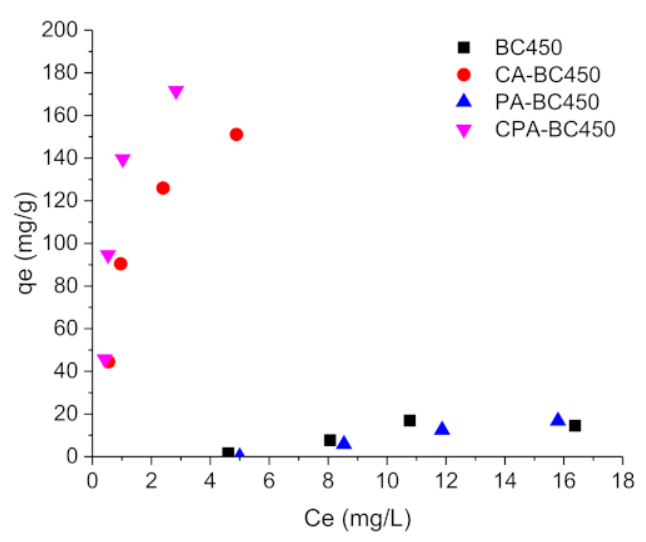

(a)

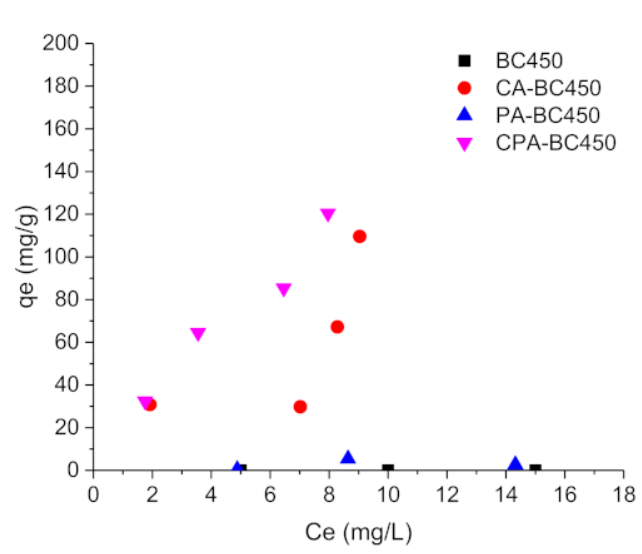

(c)

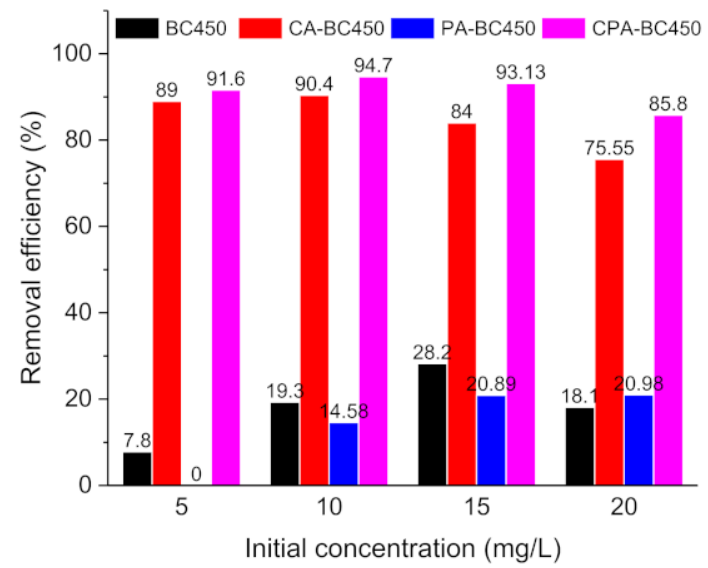

(b)

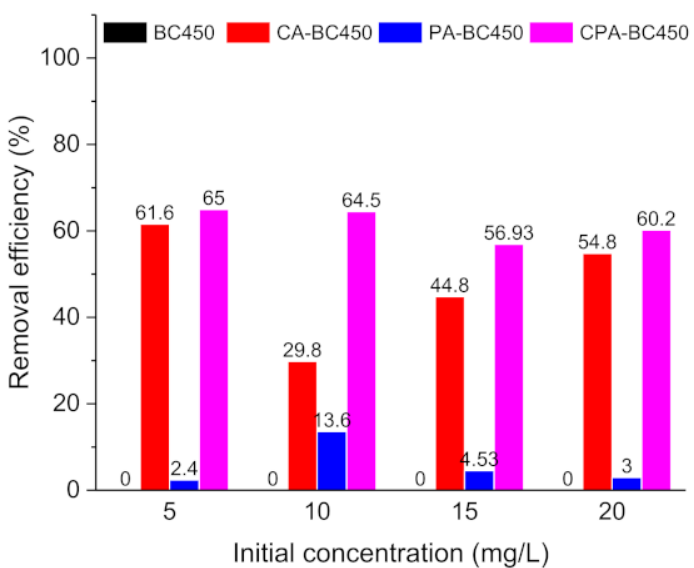

(d)

Figure 11. (a) Atrazine adsorption isotherms, (b) Atrazine removal efficiency (\%), (c) Ibuprofen adsorption isotherms, and (d) ibuprofen removal efficiency (\%) on the different adsorbents.

The variation trend of the adsorption properties of the different produced materials can be understood by considering their surface and chemical properties; indeed, the adsorption potential of carbon materials is essentially related to their surface area, porosity, and surface chemistry (surface functional groups), which are involved in both chemisorption and physisorption processes. Among the different tested activation methods, chemical activation produced char with a highly developed surface area and micro/meso-porosity, leading to improved adsorptive properties, whereas physical activation did not significantly enhance the textural properties of the raw char, and thus the adsorptive properties of both raw and physically activated char were comparable.

The parameters for the two adsorption isotherm models and their corresponding determination coefficients $\mathrm{R}^{2}$, giving the fitting of experimental data with respect to theoretical data, are presented in Table 10. The Langmuir isotherm model better describes the adsorption behavior of atrazine on CA-BC450 and CPA-BC450 samples with quite a good fit to the experimental data $\left(\mathrm{R}^{2}>0.997\right)$. This indicates that the adsorption of atrazine on these adsorbents follows a monolayer model, with strong interaction between the adsorbent and the adsorbate. The maximum adsorption capacities for CA-BC450 and CPA-BC450 samples were 182 and $208 \mathrm{mg} \mathrm{g}^{-1}$, respectively, while the maximum adsorption capacities obtained using the Freundlich model were 93 and $125 \mathrm{mg} \mathrm{g}^{-1}$, respectively. $\mathrm{K}_{\mathrm{L}}$ and $\mathrm{K}_{\mathrm{F}}$ values for the CPA-BC450 sample were higher than for CA-BC450, indicating a higher affinity between adsorbate and adsorbent for the CPA-BC450 sample [80]. For atrazine, it is well known that the H-bond, electrostatic attraction between the hydrogen atom in the polar groups and the highly electronegative heterocyclic ring in atrazine (electron donor) and 
organic partitioning play an important role in the atrazine sorption processes. In general, a deeper carbonization of organic compounds with an increase in temperature may lead to more site-specific interactions during the adsorption process. However, a temperature higher than $400{ }^{\circ} \mathrm{C}$ significantly destroys the primary active sites of organic components, such as carboxylic and phenolic moieties, which are essential components for H-bonding formation for atrazine adsorption. Chemical activation might create additional adsorption sites able to create such bonds. Moreover, atrazine molecules can be easily decomposed in weak basic or acid environments, so its exposition to a higher basic environment can result in higher adsorption/degradation. Otherwise, the CA-BC450 and CPA-BC450 samples present higher surface negative charges and then can contribute to atrazine degradation.

Table 10. Isotherm model parameters obtained from the adsorption data.

\begin{tabular}{cccccc}
\hline Adsorbate & Adsorbent & Isotherm Model & \multicolumn{2}{c}{ Parameters } & $\mathbf{R}^{\mathbf{2}}$ \\
\hline \multirow{3}{*}{ Atrazine } & $\mathrm{CA}-\mathrm{BC} 450$ & Langmuir & $\mathrm{q}_{\max }\left(\mathrm{mg} \mathrm{g}^{-1}\right), \mathrm{K}_{\mathrm{L}}\left(\mathrm{L} \mathrm{mg}^{-1}\right)$ & $181.8,1.000$ & 0.999 \\
& & Freundlich & $\mathrm{K}_{\mathrm{F}}\left(\mathrm{mg} \mathrm{g}^{-1}\right), \mathrm{n}$ & $92.7,3.148$ & 0.991 \\
\cline { 2 - 7 } & \multirow{2}{*}{$\mathrm{CPA-BC450}$} & Langmuir & $\mathrm{q}_{\max }\left(\mathrm{mg} \mathrm{g}^{-1}\right), \mathrm{K}_{\mathrm{L}}\left(\mathrm{L} \mathrm{mg}^{-1}\right)$ & $208.3,1.714$ & 0.997 \\
& & Freundlich & $\mathrm{K}_{\mathrm{F}}\left(\mathrm{mg} \mathrm{g}^{-1}\right), \mathrm{n}$ & $125.0,2.925$ & 0.915 \\
\hline \multirow{2}{*}{ Ibuprofen } & $\mathrm{CA}-\mathrm{BC} 450$ & Freundlich & $\mathrm{K}_{\mathrm{F}}\left(\mathrm{mg} \mathrm{g}^{-1}\right), \mathrm{n}$ & $0.001,0.195$ & 0.999 \\
& $\mathrm{CPA}-\mathrm{BC} 450$ & Freundlich & $\mathrm{K}_{\mathrm{F}}\left(\mathrm{mg} \mathrm{g}^{-1}\right), \mathrm{n}$ & $25.6,1.416$ & 0.895 \\
\hline
\end{tabular}

The isotherm model parameters for ibuprofen adsorption on the CA-BC450 and CPA-BC450 samples are also shown in Table 10. The Freundlich model led to a better fit $\left(\mathrm{R}^{2}>0.895\right)$ with the experimental data than the Langmuir model, which indicates that ibuprofen adsorption occurs differently on these adsorbents as compared to atrazine. The Freundlich constants $(1 / n)$ were found to be 5.124 and 0.706 for CA-BC450 and CPA$\mathrm{BC} 450$, respectively, which indicates that the adsorption of ibuprofen is more favored on CPA-BC450 than on CA-BC450. From the results obtained, it is clear that the adsorption properties of the samples developed in this study towards ibuprofen were not significant when compared to atrazine. These results may be due to the surface functional groups on the activated char surface that lead to stronger interaction of the surface with atrazine than with ibuprofen.

Table 11 summarizes the results obtained for atrazine and ibuprofen adsorption on different adsorbents. No data were found for atrazine or ibuprofen adsorption on waste tires-based char or activated char. In comparison to these different studies, the activated chars developed in this study showed higher adsorption capacity for atrazine than those reported for commercial activated carbons having surface areas of $666 \mathrm{~m}^{2} \mathrm{~g}^{-1}$ [81] and higher than those reported for agricultural waste-based char/activated chars (hemp stem [82], soybeans [83], corn stalks [83], rice stalks [83], and corn straw [84]. On the other hand, the activated chars prepared in the present work showed weak ibuprofen adsorption properties than those reported in the literature. 
Table 11. Various studies for atrazine and ibuprofen adsorption in aqueous media by various adsorbents.

\begin{tabular}{|c|c|c|c|c|c|c|c|c|}
\hline Adsorbate & Adsorbent & $\begin{array}{l}\text { Particle Size } \\
(\mathrm{mm})\end{array}$ & $\begin{array}{c}\text { BET } \\
\left(\mathrm{m}^{2} \cdot \mathrm{g}^{-1}\right)\end{array}$ & Adsorbent Dosage & $\begin{array}{l}\text { Concentration } \\
\left(\mathrm{mg} \mathrm{L} \mathrm{L}^{-1}\right)\end{array}$ & $\mathrm{T}$ & $\underset{\left(\mathrm{mg} \cdot \mathrm{g}^{-1}\right)}{\mathrm{q}_{\max }}$ & Reference \\
\hline Atrazine & Waste tire-AC * & $0.25-0.4$ & 490 & $4 \mathrm{mg} / 40 \mathrm{~mL}$ & $5-20$ & 18 & 208 & This study \\
\hline Atrazine & Hemp stem-AC & $0.5-1.0$ & 2135 & $5-100 \mathrm{mg} / 100 \mathrm{~mL}$ & 30 & N.M & 200 & [81] \\
\hline Atrazine & Commercial-AC & N.M & 666 & $10 \mathrm{mg}$ & $2-25$ & N.M & 30 & [82] \\
\hline Atrazine & Soybeans-BC ${ }^{* *}$ & $<0.6$ & 17.5 & $200 \mathrm{mg} / 100 \mathrm{~mL}$ & $5-35$ & 18 & 1.4 & [83] \\
\hline Atrazine & Corn stalks-BC & $<0.6$ & 19.6 & $200 \mathrm{mg} / 100 \mathrm{~mL}$ & $5-35$ & 18 & 1 & [83] \\
\hline Atrazine & Rice stalks-BC & $<0.6$ & 25.8 & $200 \mathrm{mg} / 100 \mathrm{~mL}$ & $5-35$ & 18 & 1.2 & [83] \\
\hline Atrazine & Corn straw-BC & $<2$ & 45 & $50 \mathrm{mg} / 100 \mathrm{~mL}$ & $5-25$ & 25 & 7 & [84] \\
\hline Ibuprofen & Waste tire-AC & $0.25-0.4$ & 490 & $4 \mathrm{mg} / 40 \mathrm{~mL}$ & $5-20$ & 18 & - & This study \\
\hline Ibuprofen & Cork waste-AC & N.M & 891 & $10 \mathrm{mg} / 15 \mathrm{~mL}$ & $20-60$ & 30 & 85 & [85] \\
\hline Ibuprofen & PET-AC & N.M & 1426 & $2.5-10 \mathrm{mg}$ & $20-120$ & 30 & 255 & [86] \\
\hline Ibuprofen & $\begin{array}{l}\text { Commercial-AC } \\
\text { (Coal) }\end{array}$ & N.M & 1156 & $2.5-10 \mathrm{mg}$ & $20-120$ & 30 & 360 & [86] \\
\hline Ibuprofen & $\begin{array}{l}\text { Commercial-AC } \\
\text { (Wood) }\end{array}$ & N.M & 899 & $2.5-10 \mathrm{mg}$ & $20-120$ & 30 & 275 & [86] \\
\hline
\end{tabular}

* Activated carbon. ** Biochar.

\section{Conclusions}

In this work, activated carbons were successfully prepared from waste tires via pyrolysis and activation processes and employed as adsorbents of atrazine and ibuprofen as organic micro-pollutant adsorbates. Thermogravimetric analysis of ground rubber tire showed that the heating rate and pyrolysis temperature in the explored range do not seem to affect the thermal degradation of the ground rubber sample, at least from a qualitative point of view, while they sensibly influence the char yields. Pyrolysis of ground rubber samples at the different heating rates was mainly complete by $550{ }^{\circ} \mathrm{C}$, and the maximum char yield was obtained at $450{ }^{\circ} \mathrm{C}$ with a heating rate of $5{ }^{\circ} \mathrm{C} \mathrm{min}{ }^{-1}$. According to the results of the char characterization, the physicochemical properties of the tire-based char samples seemed to be not too sensitive to the pyrolysis temperature. The pyrolytic chars showed high ash contents and low surface areas; therefore, activation treatments were needed to improve their properties as adsorbents. The results of the activated char characterization clearly demonstrated that the activation process led to an increase in surface area, pore volume, and surface alkalinity and a decrease in sulfur and zinc contents. The activation method has a strong influence on the evolution of the porous structure and surface structural characteristics of the resulting activated chars. The experimental results for atrazine adsorption showed that the activated chars had higher adsorption capacity than those reported in the literature. The adsorption capacity of ibuprofen on the activated chars, however, was lower than those found in the literature. Among the different tested activation methods, chemical activation produced char with a highly developed surface area and micro/meso-porosity, leading to improved adsorption properties.

Author Contributions: Conceptualization, L.L. and S.B.; methodology, L.L., S.B., and K.F.; validation, S.B., L.L., K.F.P., B.C.G. and J.P.C.; formal analysis, K.F. and C.V.; investigation, K.F; resources, L.L. and S.B.; writing-original draft preparation, K.F.; writing—review and editing, S.B. and L.L.; visualization, K.F.; supervision, L.L. and S.B.; project administration, S.B., L.L., K.F.P., B.C.G. and J.P.C.; funding acquisition, S.B. All authors have read and agreed to the published version of the manuscript.

Funding: Catalan Government (ACCIÓ) and Waste Catalan Agency (ARC) for funding the RESACTIV project, in the frame of the call "Nuclis d'economia Circular," under the grant number of RDECR18-1-0002.

Institutional Review Board Statement: Not applicable.

Informed Consent Statement: Not applicable.

Data Availability Statement: All the data are contained within the article.

Acknowledgments: The authors acknowledge the Carnot MICA institute for funding the pilot scale pyrolysis tests and IS2M technical platforms for the physicochemical characterizations. 
Conflicts of Interest: The authors declare no conflict of interest.

\section{References}

1. Mastral, A.M.; Callén, M.S.; Murillo, R.; García, T. Combustion of High Calorific Value Waste Material: Organic Atmospheric Pollution. Environ. Sci. Technol. 1999, 33, 4155-4158. [CrossRef]

2. Sathiskumar, C.; Karthikeyan, S. Recycling of Waste Tires and Its Energy Storage Application of By-Products-A Review. Sustain. Mater. Technol. 2019, 22, e00125. [CrossRef]

3. Song, W.; Zhou, J.; Li, Y.; Li, S.; Yang, J. Utilization of Waste Tire Powder for Gaseous Fuel Generation via $\mathrm{CO}_{2} \mathrm{Gasification}_{\mathrm{Using}}$ Waste Heat in Converter Vaporization Cooling Flue. Renew. Energy 2021, 173, 283-296. [CrossRef]

4. Fernández, A.M.; Barriocanal, C.; Alvarez, R. Pyrolysis of a Waste from the Grinding of Scrap Tyres. J. Hazard. Mater. 2012, 203-204, 236-243. [CrossRef]

5. Directive 2000/53/EC of the European Parliament and of the Council of 18 September 2000 on End-of Life Vehicles. Available online: https:/ / eur-lex.europa.eu/LexUriServ /LexUriServ.do?uri=CONSLEG:2000L0053:20050701:EN:PDF (accessed on 27 December 2021).

6. Hita, I.; Arabiourrutia, M.; Olazar, M.; Bilbao, J.; Arandes, J.M.; Castaño Sánchez, P. Opportunities and Barriers for Producing High Quality Fuels from the Pyrolysis of Scrap Tires. Renew. Sustain. Energy Rev. 2016, 56, 745-759. [CrossRef]

7. Council Directive 1999/31/EC of 26 April 1999 on the Landfill of Waste. Available online: https:/ / eur-lex.europa.eu/legalcontent/EN/TXT/PDF/?uri=CELEX:31999L0031\&from=en (accessed on 27 December 2021).

8. Galvagno, S.; Casu, S.; Casabianca, T.; Calabrese, A.; Cornacchia, G. Pyrolysis process for the treatment of scrap tyres: Preliminary experimental results. Waste Manag. 2002, 22, 917-923. [CrossRef]

9. Chen, D.; Yin, L.; Wang, H.; He, P. Pyrolysis Technologies for Municipal Solid Waste: A Review. Waste Manag. 2014, 34, 2466-2486. [CrossRef]

10. Kyari, M.; Cunliffe, A.; Williams, P.T. Characterization of Oils, Gases, and Char in Relation to the Pyrolysis of Different Brands of Scrap Automotive Tires. Energy Fuels 2005, 19, 1165-1173. [CrossRef]

11. Frigo, S.; Seggiani, M.; Puccini, M.; Vitolo, S. Liquid fuel production from waste tyre pyrolysis and its utilisation in a Diesel engine. Fuel 2004, 116, 399-408. [CrossRef]

12. Rodriguez, I.d.M.; Laresgoiti, M.F.; Cabrero, M.A.; Torres, A.; Chomón, M.J.; Caballero, B. Pyrolysis of Scrap Tyres. Fuel Process. Technol. 2001, 72, 9-22. [CrossRef]

13. Laresgoiti, M.F.; Caballero, B.M.; de Marco, I.; Torres, A.; Cabrero, M.A.; Chomón, M.J. Characterization of the Liquid Products Obtained in Tyre Pyrolysis. J. Anal. Appl. Pyrolysis 2004, 71, 917-934. [CrossRef]

14. Díez, C.; Martínez, O.; Calvo, L.F.; Cara, J.; Morán, A. Pyrolysis of Tyres. Influence of the Final Temperature of the Process on Emissions and the Calorific Value of the Products Recovered. Waste Manag. 2004, 24, 463-469. [CrossRef] [PubMed]

15. Mohan, A.; Dutta, S.; Balusamy, S.; Madav, V. Liquid Fuel from Waste Tires: Novel Refining, Advanced Characterization and Utilization in Engines with Ethyl Levulinate as an Additive. RSC Adv. 2021, 11, 9807-9826. [CrossRef]

16. Banar, M.; Akyıldız, V.; Özkan, A.; Çokaygil, Z.; Onay, Ö. Characterization of Pyrolytic Oil Obtained from Pyrolysis of TDF (Tire Derived Fuel). Energy Convers. Manag. 2012, 62, 22-30. [CrossRef]

17. Williams, P.T.; Brindle, A.J. Aromatic Chemicals from the Catalytic Pyrolysis of Scrap Tyres. J. Anal. Appl. Pyrolysis 2003, 67, 143-164. [CrossRef]

18. Williams, P.T.; Brindle, A.J. Catalytic Pyrolysis of Tyres: Influence of Catalyst Temperature. Fuel 2002, 81, 2425-2434. [CrossRef]

19. Pakdel, H.; Pantea, D.M.; Roy, C. Production of Dl-Limonene by Vacuum Pyrolysis of Used Tires. J. Anal. Appl. Pyrolysis 2001, 57, 91-107. [CrossRef]

20. Czajczyńska, D.; Krzyżyńska, R.; Jouhara, H.; Spencer, N. Use of Pyrolytic Gas from Waste Tire as a Fuel: A Review. Energy 2017, 134, 1121-1131. [CrossRef]

21. Luo, S.; Feng, Y. The Production of Fuel Oil and Combustible Gas by Catalytic Pyrolysis of Waste Tire Using Waste Heat of Blast-Furnace Slag. Energy Convers. Manag. 2017, 136, 27-35. [CrossRef]

22. Machin, E.B.; Pedroso, D.T.; de Carvalho, J.A. Energetic Valorization of Waste Tires. Renew. Sustain. Energy Rev. 2017, 68, 306-315. [CrossRef]

23. Pathak, P.; Sinha, S. Valorisation of waste tires into fuel and energy. In Advanced Technology for the Conversion of Waste into Fuels and Chemicals; Khan, A., Pizzi, A., Jawaid, M., Azum, N., Asiri, A., Isa, I., Eds.; Elsevier: Amsterdam, The Netherlands, 2021; pp. 109-122.

24. Xu, J.; Yu, J.; Xu, J.; Sun, C.; He, W.; Huang, J.; Li, G. High-Value Utilization of Waste Tires: A Review with Focus on Modified Carbon Black from Pyrolysis. Sci. Total Environ. 2020, 742, 140235. [CrossRef] [PubMed]

25. Gómez-Hernández, R.; Panecatl-Bernal, Y.; Méndez-Rojas, M.Á. High Yield and Simple One-Step Production of Carbon Black Nanoparticles from Waste Tires. Heliyon 2019, 5, e2139. [CrossRef] [PubMed]

26. Xu, J.; Yu, J.; He, W.; Huang, J.; Xu, J.; Li, G. Recovery of Carbon Black from Waste Tire in Continuous Commercial Rotary Kiln Pyrolysis Reactor. Sci. Total Environ. 2021, 772, 145507. [CrossRef] [PubMed]

27. Williams, P.T.; Besler, S.; Taylor, D.T. The pyrolysis of scrap automotive tyres: The influence of temperature and heating rate on product composition. Fuel 1990, 69, 1474-1482. [CrossRef] 
28. Auer, E.; Freund, A.; Pietsch, J.; Tacke, T. Carbons as Supports for Industrial Precious Metal Catalysts. Appl. Catal. A Gen. 1998, 173, 259-271. [CrossRef]

29. Dias, J.M.; Alvim-Ferraz, M.C.M.; Almeida, M.F.; Rivera-Utrilla, J.; Sánchez-Polo, M. Waste Materials for Activated Carbon Preparation and Its Use in Aqueous-Phase Treatment: A Review. J. Environ. Manag. 2007, 85, 833-846. [CrossRef]

30. Lua, A.C.; Yang, T. Effect of Activation Temperature on the Textural and Chemical Properties of Potassium Hydroxide Activated Carbon Prepared from Pistachio-Nut Shell. J. Colloid Interface Sci. 2004, 274, 594-601. [CrossRef]

31. Molina-Sabio, M.; Gonzalez, M.T.; Rodriguez-Reinoso, F.; Sepúlveda-Escribano, A. Effect of Steam and Carbon Dioxide Activation in the Micropore Size Distribution of Activated Carbon. Carbon 1996, 34, 505-509. [CrossRef]

32. Lan, X.; Jiang, X.; Song, Y.; Jing, X.; Xing, X. The Effect of Activation Temperature on Structure and Properties of Blue Coke-Based Activated Carbon by $\mathrm{CO}_{2}$ Activation. Green Process. Synth. 2019, 8, 837-845. [CrossRef]

33. Jun, T.Y.; Latip, N.H.A.; Abdullah, A.M.; Latif, P.A. Effect of Activation Temperature and Heating Duration on Physical Characteristics of Activated Carbon Prepared from Agriculture Waste. Environ. Asia 2010, 3, 143-148.

34. Gao, Y.; Yue, Q.; Gao, B.; Li, A. Insight into Activated Carbon from Different Kinds of Chemical Activating Agents: A Review. Sci. Total Environ. 2020, 746, 141094. [CrossRef] [PubMed]

35. Mozammel, H.M.; Masahiro, O.; SC, B. Activated Charcoal from Coconut Shell Using $\mathrm{ZnCl}_{2}$ Activation. Biomass Bioenergy 2002, 22, 397-400. [CrossRef]

36. Suárez-García, F.; Martínez-Alonso, A.; Tascón, J.M.D. Pyrolysis of Apple Pulp: Chemical Activation with Phosphoric Acid. J. Anal. Appl. Pyrolysis 2002, 63, 283-301. [CrossRef]

37. Okman, I.; Karagöz, S.; Tay, T.; Erdem, M. Activated Carbons From Grape Seeds By Chemical Activation With Potassium Carbonate And Potassium Hydroxide. Appl. Surf. Sci. 2014, 293, 138-142. [CrossRef]

38. Muniandy, L.; Adam, F.; Mohamed, A.R.; Ng, E.-P. The Synthesis and Characterization of High Purity Mixed Microporous/Mesoporous Activated Carbon from Rice Husk Using Chemical Activation with $\mathrm{NaOH}$ and KOH. Microporous Mesoporous Mater. 2014, 197, 316-323. [CrossRef]

39. Streat, M.; Patrick, J.W.; Perez, M.J.C. Sorption of Phenol and Para-Chlorophenol from Water Using Conventional and Novel Activated Carbons. Water Res. 1995, 29, 467-472. [CrossRef]

40. Helleur, R.; Popovic, N.; Ikura, M.; Stanciulescu, M.; Liu, D. Characterization and Potential Applications of Pyrolytic Char from Ablative Pyrolysis of Used Tires. J. Anal. Appl. Pyrolysis 2001, 58-59, 813-824. [CrossRef]

41. Allen, J.L.; Gatz, J.L.; Eklund, P.C. Applications for Activated Carbons from Used Tires: Butane Working Capacity. Carbon 1999, 37, 1485-1489. [CrossRef]

42. Brady, T.A.; Rostam-Abadi, M.; Rood, M.J. Applications for Activated Carbons from Waste Tires: Natural Gas Storage and Air Pollution Control. Gas Sep. Purif. 1996, 10, 97-102. [CrossRef]

43. Simitzis, J.; Sfyrakis, J. Activated Carbon from Lignocellulosic Biomass-Phenolic Resin. J. Appl. Polym. Sci. 1994, 54, 2091-2099. [CrossRef]

44. González, J.F.; Román, S.; Encinar, J.M.; Martínez, G. Pyrolysis of Various Biomass Residues and Char Utilization for the Production of Activated Carbons. J. Anal. Appl. Pyrolysis 2009, 85, 134-141. [CrossRef]

45. Oliveira, L.S.; Franca, A.S. Low-Cost Adsorbents from Agri-Food Wastes. In Food Science and Technology: New Research; Greco, L.V., Bruno, M.N., Eds.; Nova Science Publishers: New York, NY, USA, 2008.

46. Nahil, M.A.; Williams, P.T. Activated Carbons from Acrylic Textile Waste. J. Anal. Pyrolysis 2010, 89, 51-59. [CrossRef]

47. Nagano, S.; Tamon, H.; Adzumi, T.; Nakagawa, K.; Suzuki, T. Activated Carbon from Municipal Waste. Carbon 2000, 38, 915-920. [CrossRef]

48. Hjaila, K.; Baccar, R.; Sarrà, M.; Gasol, C.M.; Blánquez, P. Environmental impact associated with activated carbon preparation from olive-waste cake via life cycle assessment. J. Environ. Manag. 2013, 130, 242-247. [CrossRef] [PubMed]

49. Suganya, S.; Kumar, P.S. Evaluation of environmental aspects of brew waste-based carbon production and its disposal scenario. $J$. Clean. Prod. 2018, 202, 244-252. [CrossRef]

50. Chingombe, P.; Saha, B.; Wakeman, R.J. Sorption of Atrazine on Conventional and Surface Modified Activated Carbons. J. Colloid Interface Sci. 2006, 302, 408-416. [CrossRef]

51. Tsai, W.T.; Chang, Y.M.; Lai, C.W.; Lo, C.C. Adsorption of Basic Dyes in Aqueous Solution by Clay Adsorbent from Regenerated Bleaching Earth. Appl. Clay Sci. 2005, 29, 149-154. [CrossRef]

52. Zhang, Z.; O'Hara, I.M.; Kent, G.A.; Doherty, W.O.S. Comparative Study on Adsorption of Two Cationic Dyes by Milled Sugarcane Bagasse. Ind. Crops Prod. 2013, 42, 41-49. [CrossRef]

53. Kołodyńska, D.; Wnętrzak, R.; Leahy, J.J.; Hayes, M.H.B.; Kwapiński, W.; Hubicki, Z. Kinetic and Adsorptive Characterization of Biochar in Metal Ions Removal. Chem. Eng. J. 2012, 197, 295-305. [CrossRef]

54. de la Rosa, J.M.; Rosado, M.; Paneque, M.; Miller, A.Z.; Knicker, H. Effects of Aging under Field Conditions on Biochar Structure and Composition: Implications for Biochar Stability in Soils. Sci. Total Environ. 2018, 613-614, 969-976. [CrossRef]

55. Osmari, T.A.; Gallon, R.; Schwaab, M.; Barbosa-Coutinho, E.; Severo, J.B.; Pinto, J.C. Statistical Analysis of Linear and Non-Linear Regression for the Estimation of Adsorption Isotherm Parameters. Adsorpt. Sci. Technol. 2013, 31, 433-458. [CrossRef]

56. Kumar Singh, R.; Ruj, B.; Jana, A.; Mondal, S.; Jana, B.; Sadhukhan, A.K.; Gupta, P. Pyrolysis of Three Different Categories of Automotive Tyre Wastes: Product Yield Analysis and Characterization. J. Anal. Appl. Pyrolysis 2018, 135, 379-389. [CrossRef]

57. Leung, D.Y.C.; Wang, C.L. Kinetic Study of Scrap Tyre Pyrolysis and Combustion. J. Anal. Appl. Pyrolysis 1998, 45, 153-169. [CrossRef] 
58. Senneca, O.; Salatino, P.; Chirone, R. A Fast Heating-Rate Thermogravimetric Study of the Pyrolysis of Scrap Tyres. Fuel 1999, 78, 1575-1581. [CrossRef]

59. Chen, J.H.; Chen, K.S.; Tong, L.Y. On the Pyrolysis Kinetics of Scrap Automotive Tires. J. Hazard. Mater. 2001, 84, 43-55. [CrossRef]

60. Williams, P.T.; Besler, S. Pyrolysis-Thermogravimetric Analysis of Tyres and Tyre Components. Fuel 1995, 74, 1277-1283. [CrossRef]

61. Kim, S.; Park, J.K.; Chun, H.-D. Pyrolysis Kinetics of Scrap Tire Rubbers. I: Using DTG and TGA. J. Environ. Eng. 1995, 121, 507-514. [CrossRef]

62. González, J.F.; Encinar, J.M.; Canito, J.L.; Rodríguez, J.J. Pyrolysis of Automobile Tyre Waste. Influence of Operating Variables and Kinetics Study. J. Anal. Appl. Pyrolysis 2001, 58-59, 667-683. [CrossRef]

63. Ogasawara, S.; Kuroda, M.; Wakao, N. Preparation of Activated Carbon by Thermal Decomposition of Used Automotive Tires. Ind. Eng. Chem. Res. 1987, 26, 2556-2557. [CrossRef]

64. Li, S.-Q.; Yao, Q.; Chi, Y.; Yan, J.-H.; Cen, K.-F. Pilot-Scale Pyrolysis of Scrap Tires in a Continuous Rotary Kiln Reactor. Ind. Eng. Chem. Res. 2004, 43, 5133-5145. [CrossRef]

65. Cunliffe, A.M.; Williams, P.T. Composition of Oils Derived from the Batch Pyrolysis of Tyres. J. Anal. Appl. Pyrolysis 1998, 44, 131-152. [CrossRef]

66. Kaminsky, W.; Mennerich, C. Pyrolysis of Synthetic Tire Rubber in a Fluidised-Bed Reactor to Yield 1,3-Butadiene, Styrene and Carbon Black. J. Anal. Appl. Pyrolysis 2001, 58-59, 803-811. [CrossRef]

67. Sharma, A.; Pareek, V.; Zhang, D. Biomass Pyrolysis-A Review of Modelling, Process Parameters and Catalytic Studies. Renew. Sustain. Energy Rev. 2015, 50, 1081-1096. [CrossRef]

68. Acosta, R.; Fierro, V.; Martinez de Yuso, A.; Nabarlatz, D.; Celzard, A. Tetracycline Adsorption onto Activated Carbons Produced by KOH Activation of Tyre Pyrolysis Char. Chemosphere 2016, 149, 168-176. [CrossRef] [PubMed]

69. Ucar, S.; Karagoz, S.; Ozkan, A.R.; Yanik, J. Evaluation of Two Different Scrap Tires as Hydrocarbon Source by Pyrolysis. Fuel 2005, 84, 1884-1892. [CrossRef]

70. Danmaliki, G.I.; Saleh, T.A. Influence of Conversion Parameters of Waste Tires to Activated Carbon on Adsorption of Dibenzothiophene from Model Fuels. J. Clean. Prod. 2016, 117, 50-55. [CrossRef]

71. Al-Rahbi, A.S.; Williams, P.T. Production of Activated Carbons from Waste Tyres for Low Temperature NOx Control. Waste Manag. 2016, 49, 188-195. [CrossRef] [PubMed]

72. Lopez-Ramon, M.V.; Stoeckli, F.; Moreno-Castilla, C.; Carrasco-Marin, F. On the Characterization of Acidic and Basic Surface Sites on Carbons by Various Techniques. Carbon 1999, 37, 1215-1221. [CrossRef]

73. Fan, Y.; Fowler, G.D.; Zhao, M. The Past, Present and Future of Carbon Black as a Rubber Reinforcing Filler-A Review. J. Clean. Prod. 2020, 247, 119115. [CrossRef]

74. Fouladi Tajar, A.; Kaghazchi, T.; Soleimani, M. Adsorption of Cadmium from Aqueous Solutions on Sulfurized Activated Carbon Prepared from Nut Shells. J. Hazard. Mater. 2009, 165, 1159-1164. [CrossRef]

75. Korpiel, J.A.; Vidic, R.D. Effect of Sulfur Impregnation Method on Activated Carbon Uptake of Gas-Phase Mercury. Environ. Sci. Technol. 1997, 31, 2319-2325. [CrossRef]

76. Yin, C.Y.; Aroua, M.K.; Daud, W.M.A.W. Review of Modifications of Activated Carbon for Enhancing Contaminant Uptakes from Aqueous Solutions. Sep. Purif. Technol. 2007, 52, 403-415. [CrossRef]

77. Sing, K.S.W. Reporting Physisorption Data for Gas/Solid Systems with Special Reference to the Determination of Surface Area and Porosity (Provisional). Pure Appl. Chem. 1982, 54, 2201-2218. [CrossRef]

78. Lu, L.; Sahajwalla, V.; Kong, C.; Harris, D. Quantitative X-Ray Diffraction Analysis and Its Application to Various Coals. Carbon 2001, 39, 1821-1833. [CrossRef]

79. Jawhari, T.; Roid, A.; Casado, J. Raman Spectroscopic Characterization of Some Commercially Available Carbon Black Materials. Carbon 1995, 33, 1561-1565. [CrossRef]

80. Tsai, W.T.; Lai, C.W.; Su, T.Y. Adsorption of Bisphenol-A from Aqueous Solution onto Minerals and Carbon Adsorbents. J. Hazard. Mater. 2006, 134, 169-175. [CrossRef]

81. Castro, C.S.; Guerreiro, M.C.; Gonçalves, M.; Oliveira, L.C.A.; Anastácio, A.S. Activated Carbon/Iron Oxide Composites for the Removal of Atrazine from Aqueous Medium. J. Hazard. Mater. 2009, 164, 609-614. [CrossRef]

82. Lupul, I.; Yperman, J.; Carleer, R.; Gryglewicz, G. Adsorption of Atrazine on Hemp Stem-Based Activated Carbons with Different Surface Chemistry. Adsorption 2015, 21, 489-498. [CrossRef]

83. Liu, N.; Charrua, A.B.; Weng, C.H.; Yuan, X.; Ding, F. Characterization of Biochars Derived from Agriculture Wastes and Their Adsorptive Removal of Atrazine from Aqueous Solution: A Comparative Study. Bioresour. Technol. 2015, 198, 55-62. [CrossRef]

84. Zhao, X.; Ouyang, W.; Hao, F.; Lin, C.; Wang, F.; Han, S.; Geng, X. Properties Comparison of Biochars from Corn Straw with Different Pretreatment and Sorption Behaviour of Atrazine. Bioresour. Technol. 2013, 147, 338-344. [CrossRef]

85. Mestre, A.S.; Pires, J.; Nogueira, J.M.F.; Carvalho, A.P. Activated Carbons for the Adsorption of Ibuprofen. Carbon 2007, 45, 1979-1988. [CrossRef]

86. Mestre, A.S.; Pires, J.; Nogueira, J.M.F.; Parra, J.B.; Carvalho, A.P.; Ania, C.O. Waste-Derived Activated Carbons for Removal of Ibuprofen from Solution: Role of Surface Chemistry and Pore Structure. Bioresour. Technol. 2009, 100, 1720-1726. [CrossRef] [PubMed] 